\title{
The Impact of Competitive Bidding on the Market Prospects for Renewable Electric Technologies
}

Blair G. Swezey

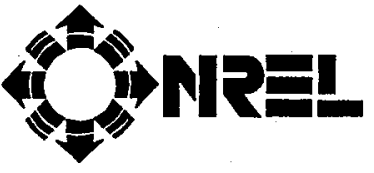

National Renewable Energy Laboratory (formerly the Solar Energy Research Institute) 1617 Cole Boulevard

Golden, Colorado 80401-3393

Operated for the U.S. Department of Energy by the Midwest Research Institute under Contract No. DE-AC02-83CH10093

Prepared under Task No. AS815440

September 1993 


\section{NOTICE}

NOTICE: This report was prepared as an account of work sponsored by an agency of the United States government. Neither the United States government nor any agency thereof, nor any of their employees, makes any warranty, express or implied, or assumes any legal liability or responsibility for the accuracy, completeness, or usefulness of any information, apparatus, product, or process disclosed, or represents that its use would not infringe privately owned rights. Reference herein to any specific commercial product, process, or service by trade name, trademark, manufacturer, or otherwise does not necessarily constitute or imply its endorsement, recommendation, or favoring by the United States government or any agency thereof. The views and opinions of authors expressed herein do not necessarily state or reflect those of the United States government or any agency thereof.

$$
\begin{gathered}
\text { Printed in the United States of America } \\
\text { Available from: } \\
\text { National Technical Information Service } \\
\text { U.S. Department of Commerce } \\
5285 \text { Port Royal Road } \\
\text { Springfield, VA 22161 } \\
\text { Price: Microfiche A01 } \\
\text { Printed Copy A05 }
\end{gathered}
$$

Codes are used for pricing all publications. The code is determined by the number of pages in the publication. Information pertaining to the pricing codes can be found in the current issue of the following publications which are generally available in most libraries: Energy Research Abstracts (ERA); Government Reports Announcements and Index (GRA and I); Scientific and Technical Abstract Reports (STAR); and publication NTIS-PR-360 available from NTIS at the above address. 


\section{Preface}

One intended result of federal investments in renewable energy research and development (R\&D) programs is the adoption and use of renewable energy technologies in the energy marketplace. Insights into the nature of energy markets can help to assure that the technologies being developed are compatible with these markets. This study examines the structure of competitive bidding programs for new generation in the electric utility sector and the impact that bidding programs are having on the competitive viability of renewable energy technologies.

The Analytic Studies Division (ASD) of the National Renewable Energy Laboratory (NREL) supports the long-range planning of the overall federal renewable energy R\&D program, both at NREL and the U.S. Department of Energy (DOE), by conducting analyses on aspects of energy market competition that are relevant to the present and future deployment of renewable energy technologies. The ASD reports on these efforts to DOE and NREL managers to enhance their awareness of competitive and institutional factors that may impact on the successful deployment of renewable energy technologies in the marketplace.

This study was conducted for the Office of Utility Technologies (OUT) in the Office of Energy Efficiency and Renewable Energy at DOE. The author thanks Garry Moore, Allan Hoffman, and Joe Galdo of DOE, and Lynn Coles and Tom Bath of NREL for their general support. The author also thanks Susan Anson and Shaine Tyson of NREL for research support at various stages of this project and Mary Anne Dunlap for editorial assistance. Hope Robertson, publisher of Robertson's Current Competition, provided the author with selected data on utility competitive bidding solicitations.

The text of the report was improved greatly through comments received from several peer reviewers: Dan Alpert (Sandia National Laboratories), Dan Cleverdon (BNF Technologies, Inc.), Michael Hachey (New England Power Service Company), Kevin Porter (NREL), Robert Putnam (Niagara Mohawk Power Corporation), and Nancy Rader (Hansen, McOuat, Hamrin \& Rohde, Inc.). However, the interpretation of the data and information presented in this report remains the sole responsibility of the author.

Approved for the

NATIONAL RENEWABLE ENERGY LABORATORY

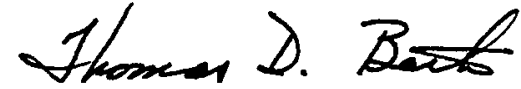

Thomas D. Bath, Director Analytic Studies Division

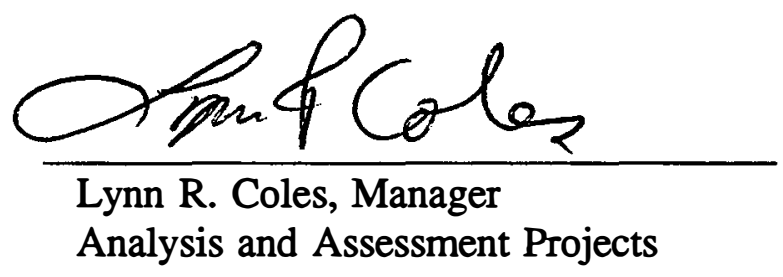

iii 


\section{Executive Summary}

This report examines important concerns regarding the ability of renewable-energy-based generation projects to compete with fossil-fuel-based projects in competitive bidding solicitations.

An analysis of state and utility bidding results finds that, on a relative basis, less renewableenergy-based capacity is being contracted for by utilities under competitive bidding than under past methods of utility contracting with qualifying facilities (QFs) under the Public Utility Regulatory Policies Act (PURPA) of 1978. Even though through the 1980s some 10,000 MW of renewable electric projects were developed, representing roughly $40 \%$ of all QF development, only $12 \%$ of the total capacity selected under competitive bidding through 1992 was renewables based (about $1400 \mathrm{MW}$ ).

Price is the paramount factor working against greater selection of renewables under competitive bidding. The dramatic decline in fossil fuel prices during the 1980s, along with overcapacity in the utility generation market, has caused utility avoided costs to fall. Because of their high capital costs, renewables projects compete poorly in excess capacity markets. For this same reason, along with operational considerations, renewables do not compete well to serve peaking or intermediate power needs. However, renewables have been selected in several base load solicitations where renewable energy resource economics have been favorable.

To date, competitive bidding solicitations have emphasized price and operational considerations over other project attributes such as environmental, fuel diversity, and fuel price stability values. The challenge facing the renewables industry under competitive bidding is to assure that bidding approaches are developed that fully account for all of the costs and benefits of generation options but also recognize the special characteristics and operational limitations of renewables projects.

Examples are provided of utility solicitations through which cost-effective renewable energy projects were selected by including many of these considerations. When similar types of solicitations cannot be easily established but renewables are highly valued, renewable energy setasides offer an alternative that assures the recognition of renewables-specific resource and project attributes while retaining the competitive benefits of traditional bidding schemes. Two states have already established renewables set-asides, and several utilities have experimented with renewables-only solicitations. 


\section{Table of Contents}

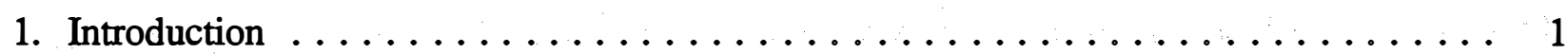

2. Overview of Competitive Bidding $\ldots \ldots \ldots \ldots \ldots \ldots \ldots \ldots \ldots \ldots \ldots$

3. Competitive Bidding and Renewable Energy $\ldots \ldots \ldots \ldots \ldots \ldots \ldots \ldots$

4. Conclusions and Discussion ......................... 19

Appendix — State by State Review of Competitive Bidding Results ......... A - 1

\section{List of Figures}

Figure 2 -1. Supply-side bidding RFPs issued $\ldots \ldots \ldots \ldots \ldots \ldots \ldots \ldots \ldots$

Figure 2-2. History of competitive bidding in the United States........... 5

Figure 2-3. Generalized utility competitive bidding process $\ldots \ldots \ldots \ldots \ldots \ldots 6$

Figure 3-1. U.S. bidding winners through 1992 (nonfuel-specific supply solicitations

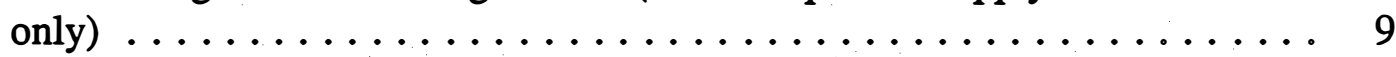

Figure 3-2. Competitive bidding participation $\ldots \ldots \ldots \ldots \ldots \ldots \ldots \ldots \ldots \ldots \ldots$

Figure 3-3. Ratepayer exposure from front-loaded contracts .............. 14 


\section{Introduction}

The Public Utility Regulatory Policies Act of 1978 (PURPA) helped usher in a new era of competition in electric power generation. Expressly formulated to encourage the development of fossil fuel conserving technologies, namely cogeneration systems and small power generators utilizing waste fuels and renewable energy, PURPA removed several institutional barriers to the development of these smaller scale, non-utility-owned-and-operated power plants that became known as "qualifying facilities" (QFs). First, electric utilities were required to interconnect with and provide backup power to QFs. Second, utilities were required to purchase power from these developers at "avoided cost," or the cost that the utility would have incurred by supplying the power itself. And finally, PURPA exempted cogenerators, and small power producers within a particular size class, from certain state and federal utility regulatory requirements. ${ }^{1}$

PURPA has proven much more successful at encouraging alternative power development than originally envisioned. While it was projected that PURPA incentives would result in 12,000 MW of QF development by 1995, more than 32,000 MW of new PURPA-qualifying cogeneration and small power capacity had actually been developed by the end of $1991 .^{2}$ Much of the impetus for this development came from the high avoided cost power purchase schedules that were established by some states in the early years of PURPA implementation. In particular, a large amount of QF development has occurred in Califomia, where favorable avoided cost pricing terms offered in 1984 and 1985 spurred thousands of megawatts of QF contract signings. The California Standard Offer 4 (SO 4) contracts, pegged to projections of rising oil prices, offered contract terms of 15 to 30 years, with fixed energy and capacity payments for the first 10 years. The purpose of these contracts was to "provide QF developers with long-term price certainty needed to obtain financing for long-term, high-capital cost projects." ${ }^{13}$ The Califomia experience was mirrored to lesser degrees in several other states.

\footnotetext{
${ }^{1}$ W. Meade and K. Porter, Trends in State Utility Regulation Affecting Renewable Energy, Renewable Energy Institute, March 1987.

${ }^{2}$ The $12,000 \mathrm{MW}$ projection was made by the Federal Energy Regulatory Commission in its 1980 Environmental Assessment prepared in conjunction with its PURPA Section 201 and 210 rulemakings. See Pfeffer, Lindsay \& Associates, Emerging Policy Issues in PURPA Implementation, Prepared for the U.S. Department of Energy, Office of Coal and Electricity Policy, DOE/PE/70404--H1, March 1986, pp. 3.11-3.13.
}

The Edison Electric Institute (EED) estimates that 32,444.8 MW of post-PURPA developed qualifying capacity was in place at the end of 1991. See EEI, 1991 Capacity and Generation of Non-Utility Sources of Energy, 01-92-08, November 1992.

${ }^{3}$ Final Report to the Legislature on: Joint CEC/CPUC Hearings on Excess Electrical Generating Capacity, June 1988, P150-87-002. 
The utility industry has argued for many years that PURPA has required the purchase of power from private developers that was unneeded. ${ }^{4}$ The slower electricity demand growth of the late seventies and early eighties, coupled with the completion of many large base load power plants, left many utilities with surplus capacity. Utilities argue that their own plants are underutilized because of mandatory QF power purchases. More recently, the dramatic decline in fossil fuel prices has led the industry to argue that old power purchase contracts are resulting in overpayments to QF operators at the expense of ratepayers. ${ }^{5}$ While this may indeed be true, based on today's lower avoided costs, some states have determined that existing QF payments continue to be justified. ${ }^{6}$

Determination of avoided cost has always been difficult because of uncertainty regarding future fuel costs, technology development, and regulation. Regulators have had to balance the concerns that high avoided costs might lock utilities and their ratepayers into purchasing too much power at too high a cost against concerns that avoided costs that are set too low might discourage desirable nonutility power development. Because of the mixed results of past efforts, regulators and utilities are increasingly tuming to an alternative method for both determining avoided cost and allocating power purchase contracts: the establishment of competitive bidding processes for new resource procurement.

However, the move toward competitive bidding raises several issues relating to renewable energy development. First, to what extent may bidding programs be undermining a fundamental

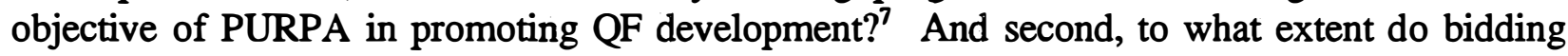
program selection criteria adequately identify and value the many different attributes, price and nonprice, of resource and technology options? Not all attributes, positive or negative, may be

\footnotetext{
${ }^{4}$ See, for example, the discussion in S. Nola and F. Sioshansi, "The Role of the US Electric Utility Industry in the Commercialization of Renewable Energy Technologies for Power Generation," Annual Review of Energy 1990, Annual Reviews, Inc., pp. 99-119.

${ }^{5}$ See, for example, "Power Glut Jolts Northeastem Electricity Producers: Large Utilities Buy Out Contracts With Independents to Reduce Costs," Wall Street Journal, April 20, 1993.

${ }^{6}$ For example, ratepayers in California are paying more, on a cost of energy basis, for utility-owned plants completed in the 1980s than for QF power purchases. See CEC/CPUC, Supra Note 3. The Connecticut Department of Public Utility Control (DPUC) has determined that the QF "projects that are operating have helped CL\&P (Connecticut Light and Power) reduce its dependence on oil by diversifying the fuel mix. The benefits will continue and increase as more projects come on line." See DPUC Review of Electric Utilities' Reports Regarding the Status of Power Purchase Agreements and Conservation and Load Management Programs, Decision, Docket No. 90-04-01, March 13, 1991.

${ }^{7}$ For instance, a 1986 report to the U.S. Department of Energy (See Pfeffer, Lindsay \& Associates, Inc., Supra Note 2) notes that:
}

A close examination of the legislative history of Title II of the Public Utility Regulatory Policies Act of 1978 (PURPA) suggests that Congress was responding to a diverse set of concerns when it enacted Sections 201 and 210 relating to cogeneration and small power production. When viewed in the context of the overall legislative agenda of the National Energy Act, these concerns reflected a desire to encourage development of certain types of alternative power supplies (QFs) as a means of improving the overall efficiency of electric power supply, displacing the use of oil and natural gas in electricity generation and providing greater diversity in the nation's sources of electric power supply. 
fully accounted for in the bid evaluation process. Bidding evaluations that fail to capture many of the nonprice benefits of renewables, or recognize the operational limitations of some renewables, presumably would result in the selection of little renewables capacity.

In an attempt to answer these questions, this report reviewed the design and results of utility competitive bidding solicitations conducted in 20 states, and by three multistate utility entities, through 1992. Although a rigorous statistical analysis of these results was not performed, we believe that there is strong circumstantial evidence that renewables, in general, are not performing well under competitive bidding.

Section 2 provides a brief status report on bidding in the United States and a conceptual description of a typical bidding procedure. Section 3 identifies and describes a number of issues related to the treatment of renewables in bidding programs. Section 4 presents conclusions and a discussion of how some states and utilities have specifically addressed renewables within the bidding process. Finally, the Appendix summarizes state-specific bidding activities and results. 


\section{Overview of Competitive Bidding}

\section{Status of Competitive Bidding}

Competitive bidding solicitations for new electric capacity resources have been conducted in 25 states (Figure 2-1). Not all of these states have formal rules on competitive bidding. In several states, utilities have conducted bidding without formal rulemakings.

Those states in which bidding solicitations have been held are generally located in the New England, Mid-Atlantic, and Pacific regions where near- or mid-term capacity needs had been identified. In some states, bidding has been adopted as a fundamental component of a least cost or integrated resource planning process. Finally, there are several states in which utilities, almost exclusively public entities, have used bidding as a mechanism to test the competitiveness of wholesale power purchases. Those states that are not considering bidding generally have excess capacity, which has obviated the need for new resource procurement mechanisms or resulted in low avoided cost utility payment schedules; this situation has deterred non-utility project proposals.

Through 1992, nearly 100 bidding request for proposals (RFPs) were issued in the United States, requesting a total of more than 25,000 MW of resources. ${ }^{8}$ As Figure 2-2 illustrates, U.S. bidding activity reached a peak in 1989 in terms of both the number of RFPs issued and the total amount of capacity solicited.

\section{Competitive Bidding Conceptualized}

A simplified schematic of a typical utility competitive bidding process is illustrated in Figure 2-3. First, the utility makes a determination of need for additional power supply, both in terms of quantity (total megawatts) and capacity type (e.g., base load, intermediate, or peaking). A competitive solicitation is made, and bids are received from potential project developers. The bids are initially screened or ranked on the basis of price; the most attractive of these bids are selected to enter a final evaluation process. This evaluation process examines several additional factors, here referred to collectively as nonprice factors, to assure the utility that both the project and the developer meet a host of other desirable operational and financial criteria. In the typical bidding scheme, price is the most important selection determinant.

Five general categories incorporate the majority of bidding selection criteria: price, operational factors, viability and finance, fuel-related factors, and other nonprice factors. Important elements of these categories are summarized here.

\footnotetext{
${ }^{8}$ This data was derived from Robertson's Current Competition, various issues. Capacity limits were not specified in three of the RFPs.
} 


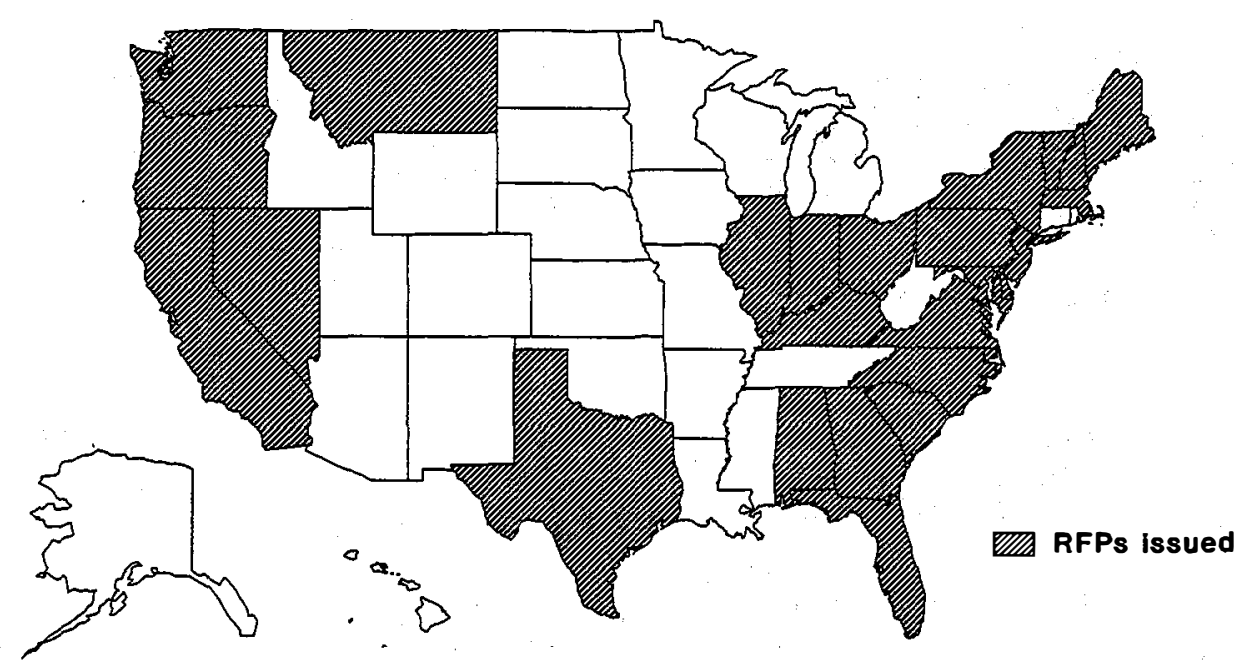

Figure 2-1. Supply-side bidding RFPs issued

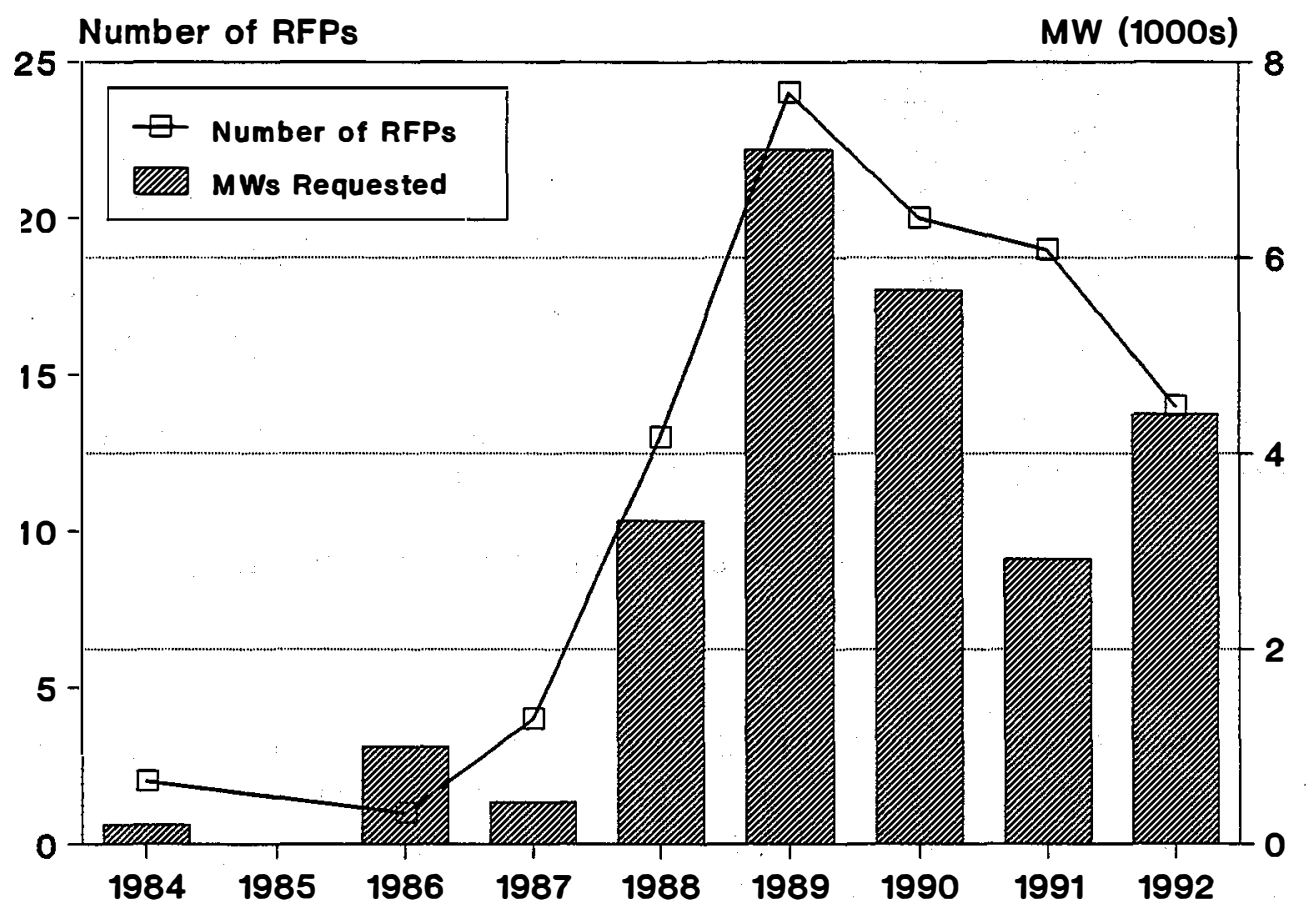

Figure 2-2. History of competitive bidding in the United States 

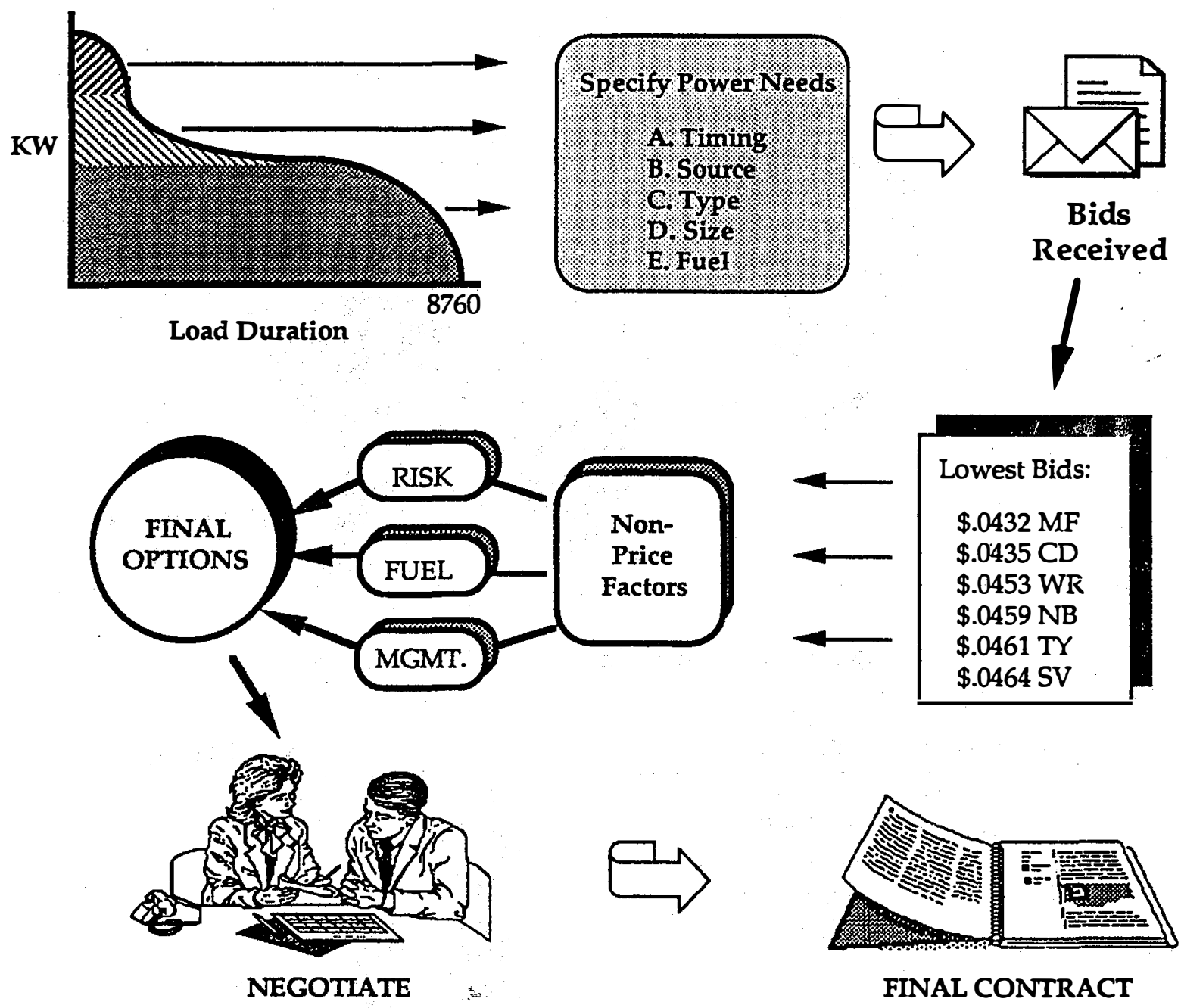

FINAL CONTRACT

Copyright @ 1989. Electric Power Research Institute. EPRI CU-6089. Bidding for Electric Resources: An Industry Review of Competitive Bid Design and Evaluation. Reprinted with Permission

Figure 2-3. Generalized utility competitive bidding process

\section{Price}

Price is the primary evaluation factor in all bidding programs. However, the price criteria can be different among RFPs. Project ranking might be based on first cost, levelized cost, or total present value over some specified time period. Some RFPs specify a price ceiling set by the utility's predetermined avoided cost, while others may not specify a price.

Price structure is often an important element of the overall price score. Typically, payment streams that match the utility's avoided cost are favored, and front-loaded payments are penalized. The relative stability of the price stream is also an important consideration, i.e., the degree of fuel price escalation and fluctuation risk that the utility is expected to accept over the lifetime of the project. 
Finally, a utility may value the ability to economically dispatch the proposed project. With direct control over a plant's operation, the utility can, within certain minimum operating constraints, take more or less of a project's output in order to economically optimize the operation of its own generation and other purchase options. This represents a level of control not universally available to utilities under past QF contracting procedures.

\section{Operational Factors}

There are a host of operational criteria that are often considered in bid evaluations. These deal primarily with the generating characteristics and response capabilities of a proposed project. For reliability, as well as economic purposes, utilities consider dispatchable plants to be of greatest operational value to their systems. Such utility control allows for better coordination of total system operating characteristics.

The proposed project site may be another important consideration for the utility. . A utility might consider a generating plant located near a load center to be of greater value than a remotely sited plant because of the potential for reduced transmission and distribution (T\&D) stresses and losses and the associated positive impact on system reliability. Also, a utility may not be willing to arrange wheeling for a project located outside of its service territory.

\section{Viability and Finance}

Consideration also is given to the perceived ability of a project developer to obtain financing and to bring the project on-line on schedule. Higher marks often are given to developers having a proven track record in project development, a project site and permitting already secured, and a construction and delivery schedule that matches the utility's resource need. In addition, a developer is often asked to provide a security bond to legitimize the bid, to ensure that development milestones are met, or to guarantee long-term power delivery.

\section{Fuel-Related Factors}

Bid evaluation might give some credit to projects powered by fuel sources indigenous to the state or by sources that diversify the existing utility fuel mix and thus provide some reduction in longer term fuel supply risks. Credit might also be given to developers who have already secured fuel supply contracts.

\section{Other Nonprice Factors}

Finally, there are other factors that might be considered in bid evaluation. These deal primanily with environmental impacts, such as air emissions and waste generation, but might also include economic development impacts such as in-state job creation. 


\section{Competitive Bidding and Renewable Energy}

This section addresses important concerns regarding the ability of renewable-energy-based generation projects to compete with traditional fuels and technologies in bidding solicitations. These concerns derive from the following observation: Through the 1980s, some 10,000 MW of renewable electric projects were developed under PURPA, representing roughly $40 \%$ of all QF development. ${ }^{9}$ Under competitive bidding, renewable energy sources represent only $12 \%$ of the total capacity selected (Figure 3-1). Although there is some overlap in these statistics, it appears that renewables are faring worse in competitive bidding than in the past under traditional PURPA-related utility procurement mechanisms.

The most plausible explanation for this difference is that bidding represents a more competitive market environment for renewables-based projects and that many of the renewables projects developed during the 1980s, under higher avoided cost contracts, would not be economically viable today. Utility avoided costs have fallen dramatically because of excess capacity in many regions and lower fuel prices. For instance, in California, the avoided cost for the Pacific Gas and Electric Company has fallen from a peak of $8.5 \phi / \mathrm{kWh}$ in 1984 to just under $4.0 \phi / \mathrm{kWh}$ at present. ${ }^{10}$ Similarly, the avoided cost ceiling price used by Central Maine Power in its bidding solicitations fell from a level of $8.9 \phi-10.8 \varnothing / \mathrm{kWh}$ in 1984 to $5.6 \varnothing / \mathrm{kWh}$ by $1987 .{ }^{11}$

There may be some validity to the argument that renewables are less competitive today. For instance, the first solar thermal plants installed in California by Luz Intemational, Ltd., generate power at $25 \phi / \mathrm{kWh}$ (in real levelized dollars). And many early wind energy plants have costs of $10 \phi-15 \phi / \mathrm{kWh}$ or higher. However, the cost-effectiveness of these technologies is improving. The cost of solar thermal power has dropped to $8 \phi-10 \phi / \mathrm{kWh}$, and the next generation of wind energy technology promises levelized costs of $5 \notin / \mathrm{kWh}$ or less. The longer term timing requirements of some bidding solicitations make it possible that advanced technologies could be considered. Furthermore, projects based on these so-called "emerging" renewable energy technologies make up only about $20 \%$ of post-PURPA renewable energy capacity. Most of the renewables-based QF capacity installed over this period consists of more "conventional" biomass, hydropower, and geothermal projects, which are already cost competitive in many regions. ${ }^{12}$

\footnotetext{
${ }^{9}$ These figures are NREL-developed estimates based on data contained in: Edison Electric Institute, 1989 Capacity and Generation of Non-Utility Sources of Energy, 04-91-03, March 1991.

${ }^{10}$ Pacific Gas and Electric Company, Cogeneration and Small Power Production Report, to the California Public Utilities Commission, First Quarter 1991.

${ }^{11} \mathrm{~J}$. Hamrin, et al., Pricing New Generation of Electric Power: A Report on Bidding, National Independent Energy Producers, September 1987, pp. 2-17.

${ }^{12}$ Supra Note 9.
} 


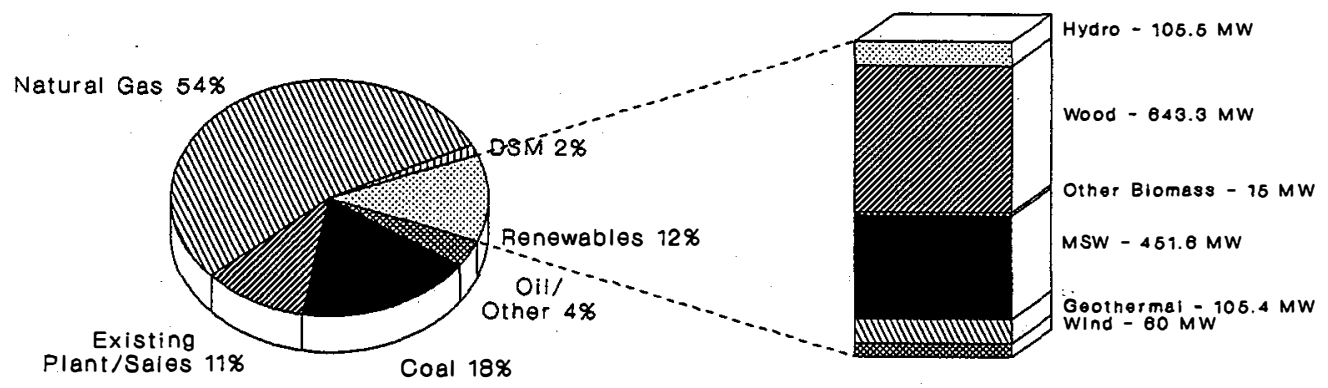

Figure 3-1. U.S. bidding winners through 1992 (nonfuel-specific supply solicitations only)

It also might be postulated that the "best" renewable resources were developed during the 1980s and that one reason fewer renewables-based projects are being selected is that the remaining resources are marginal. Also, the regions where bidding is occurring may not possess attractive renewable energy resources. Although regional variations in the availability and magnitudes of particular renewable resources do exist, studies have shown that renewable energy resources are abundant throughout the United States and more than adequate, in total quantity, to meet most electric power needs. ${ }^{13}$

Finally, it has been suggested that the inherent structure of most competitive bidding processes works against greater selection of renewables. ${ }^{14}$ While there may be other factors at work, the nature of RFP design and evaluation criteria is one very plausible explanation for the general lack of success of renewable energy projects in bidding solicitations. The remainder of this section focuses on the different elements of the bidding process and how these elements may impact the prospects for renewables bidding success either positively or negatively. This information is based on NREL and other analyses of utility bidding RFPs and results. Although bidding programs are by no means homogeneous in design and scope, and evaluation criteria will vary, there are a number of generic characteristics that can be identified and discussed.

\footnotetext{
${ }^{13}$ See, for example, The Potential of Renewable Energy: An Interlaboratory White Paper, Prepared for the Office of Policy, Planning and Analysis, U.S. Department of Energy, Solar Energy Research Institute, SERI/TP-260-3674, March 1990.
}

${ }^{14}$ R. Sherman, Jr. and W. Wellford, Esq., "Bidding Recommendations," Independent Energy, July/August 1990. 


\section{Duty Cycle}

In a bidding RFP, a utility may request projects based on its need for a particular duty cycle, that is base load, intermediate, or peaking power. Renewable energy technologies vary in their load response capabilities. Historically, hydropower plants have provided base load power but today are increasingly used to follow load. Biomass and geothermal technologies are generally operated as base load. Solar and wind resources are intermittent but in many cases have been shown to have seasonal or even daily coincidence with utility peaks. These latter resources can also be "firmed," at additional capital cost, with conventional fossil or storage technologies. Generally, however, stand-alone intermittent renewables do not lend themselves to utility dispatch.

Several utility bidding RFPs have sought peaking capacity only. However, because of their higher capital costs, renewable energy technologies (RETs) will yield lower generation costs when operated in a base load or "as available" mode. Since most renewables cannot easily provide dedicated peaking capacity, no RET projects have been selected in peaking solicitations.

\section{Time Frame}

The time frame of utility need can affect the selection of renewables projects in bidding. All other things equal, short lead time procurements could potentially favor more established RETs because many of these technologies are of modular scale and often require less burdensome frontend permitting and fuel procurement arrangements than larger scale fossil-based systems. On the other hand, some RET-based projects may benefit from longer lead times to allow for more extensive resource confirmation and the incorporation of pending technology improvements.

Most of the "quick start" RFPs have requested peaking or economy energy and, as noted previously, RETs have not fared well in these types of solicitations. Renewables have fared better in longer time frame solicitations. Two recent examples are the selection of a 50-MW advanced technology wind energy project by the Sacramento Municipal Utility District (SMUD), having a 1996 on-line date, and the selection of 58-aMW (average megawatts) of a diverse set of renewables in the second Puget Sound Power and Light solicitation for the 1995-1998 time frame.

\section{Solicitation Size}

There appears to be a negative association between the total capacity requested in a bidding solicitation and the success of renewables against nonrenewable fuel types. That is, renewables tend to exhibit more favorable economics at smaller sizes than fuel-based technologies, which are more subject to scale economies. In Massachusetts, for example, renewables represent $32 \%$ of winning capacity in solicitations of $100 \mathrm{MW}$ or less, while RETs represent only 5\% of the winning capacity in solicitations that ranged from 132 to $200 \mathrm{MW}$. In large capacity solicitations, the economies of larger fossil-based plants tend to dominate. 


\section{Participation}

One key element impacting the viability of RET projects in competitive bidding is the extent to which solicitations are open to different fuel types or project development entities. At the extreme, bidding solicitations may be "all source," in which any potential project developer may participate, including utilities, independent power producers (IPPs, defined as nonutility-owned generators that are not QFs under PURPA), ${ }^{15}$ and demand-side projects. ${ }^{16}$

Initially, states and utilities used bidding as a mechanism to control and select from large quantities of QF development offers. As bidding has expanded and been refined, the potential pool of projects has been expanded to include both IPPs and utilities; the majority of RFPs in recent years have included IPP and utility participation (Figure 3-2). Only in four states (Florida, Maine, Massachusetts, and Virginia) have utilities held QF-only solicitations. Since then, bidding in three of these states has been expanded to include non- $\mathrm{QF}$ entities in recognition of the potential cost benefits of greater competition. For example, the Massachusetts Department of Public Utilities found that "the inclusion of IPPs in the existing RFP solicitations is consistent with the companies' obligation to provide reliable, least-cost service ..."17 Only one of five RFPs in Florida has been QF-only.

On the other hand, in Califomia, where the QF industry has had its greatest impact, the Public Utilities Commission (CPUC) has decided to limit bidding participation to QFs. While the CPUC "agree(s) in principle with the many parties that support all-source bidding as a necessary component of a fully competitive resource procurement process," it found that:

... new QF projects are fundamentally disadvantaged in the marketplace. They have no assured access to utilities acquiring resources, nor is their full resource value likely to be recognized. Under these circumstances, opening the auction to non-QF entities irrespective of the market power such entities may have will weaken competition, not increase it.

In addition, the CPUC recognizes that QF generators were created by PURPA for specific public policy reasons and believes that "the QF category has not outlived its usefulness."18

\footnotetext{
${ }^{15}$ With the passage of the Energy Policy Act of 1992 (PL 102-486), IPPs have effectively been transformed into exempt wholesale generators (EWGs) with reform of the Public Utility Holding Company Act of 1935.

${ }^{16}$ Some utilities have included demand-side projects in all source solicitations, while other utilities have chosen to hold separate demand-side auctions. Here we wish to delineate only by whether non-QF entities are allowed to bid.

${ }^{17}$ Massachusetts Department of Public Utilities, Investigation by the Department of Public Utilities on its own motion into proposed rules to implement integrated resource management practices for electric companies in the Commonwealth, D.P.U. 89-239, August 31, 1990.

${ }^{18}$ California Public Utilities Commission, Phase $1 B$ Opinion: Changes to Final Standard Offer 4 for Use in Conjunction with the 1990 Electricity Report, Decision 91-06-022, June 5, 1991, p. 12.
} 


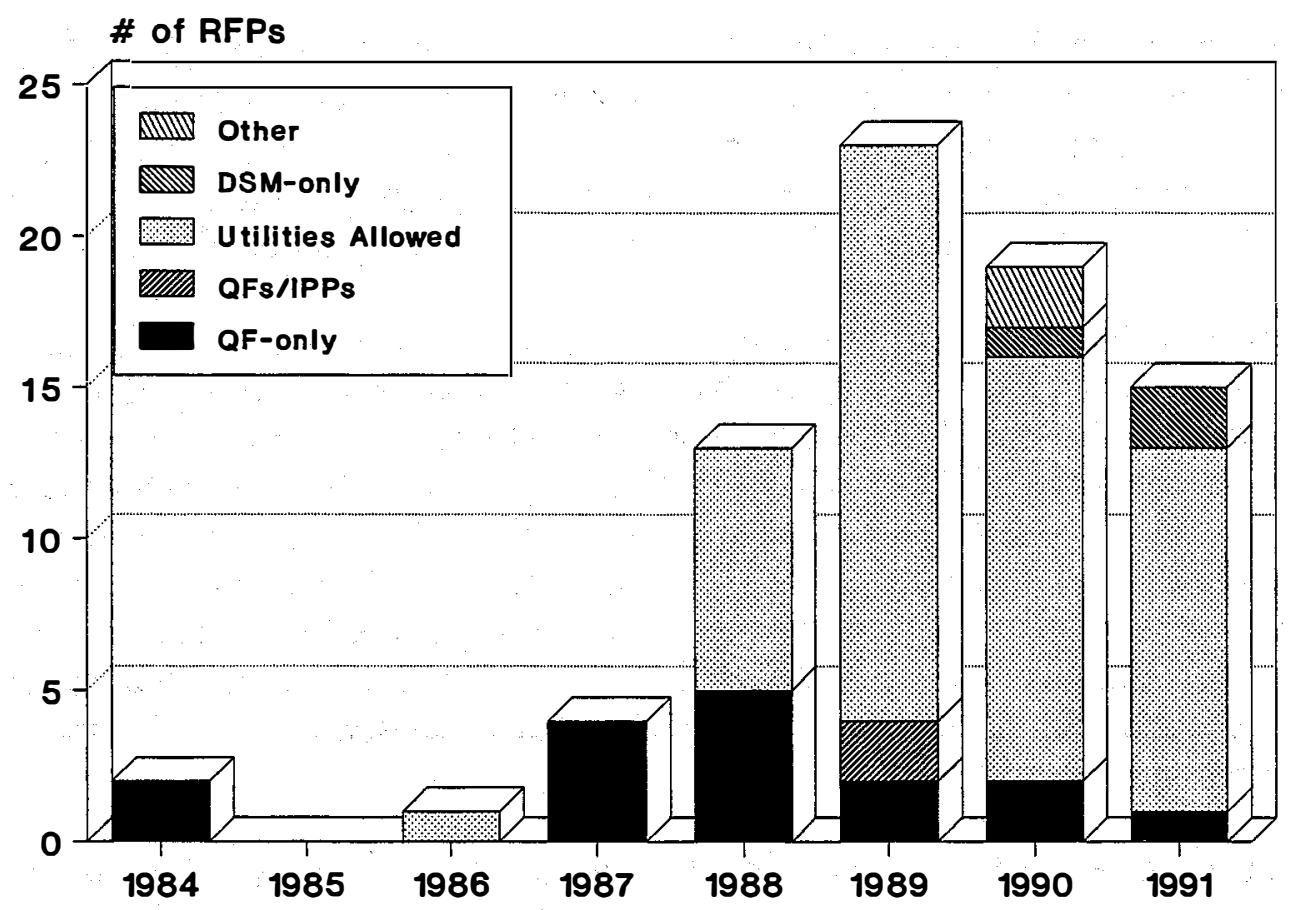

Figure 3-2. Competitive bidding participation

Given the limited sample of QF-only RFPs, both in terms of numbers and location, it is difficult to make conclusive statements regarding the impact of non-QF participation on the success rate of renewables projects. In Maine, for example, where four QF-only solicitations have been held by Central Maine Power (two in 1984 and two in 1987), 100\% of the supply-side capacity procured was renewables based. The majority of this capacity is from wood-fired projects because Maine has plentiful wood waste supplies and well established wood and paper industries, leading to favorable economics.

On the other hand, in Massachusetts, where 12 utility QF-only solicitations were held from 1987 to 1990 , only $19 \%$ of the aggregate capacity chosen was from renewables. While several smaller utility solicitations have tended to favor renewables (32\% of winning capacity), bidding in the state has been dominated by Boston Edison (BECO) whose evaluation criteria have contained heavy penalties for front-loading of costs (see discussion in following section). Renewables represent less than 5\% of the winning capacity in the three BECO solicitations.

In Florida Power Corporation's QF-only RFP, $14 \%$ of the capacity chosen was renewables based. And in the 1986 Virginia Power QF-only solicitation, renewables accounted for only 6\% of the capacity selected. Nonetheless, most of these results compare favorably to the $7 \%$ of renewables capacity procured in the 70 to 80 other solicitations combined, a renewables total of just more than $600 \mathrm{MW}$. 
Many states with bidding still allow QFs to negotiate standard offer contracts outside of the bidding process; however, these projects are subject to maximum size thresholds, generally ranging from 1 to $10 \mathrm{MW}$, which do not favor economies of scale. In Florida, a statewide standard offer contracting process exists for QFs to negotiate contracts outside of bidding within an overall subscription limit.

\section{Pricing Schedule}

Although the pattern of electricity pricing is important to all projects, it is critical to many RETbased projects because of the capital intensive nature of these investments. Since many RET projects incur a substantial portion of their life cycle costs up front, some mechanism must be available to recover the greater relative amortization of these costs in the early years of operation. This is not a new or special phenomenon. Traditionally, the costs of utility capital projects have entered the rate base when they become "used and useful." Before the 1970s, the rate impacts of these investments were more than offset by the increasing productivity of the utility industry. However, beginning in the 1970s, utility productivity improvements slowed and the capital costs of large coal and nuclear plants increased dramatically, leading to "rate shock" as these investments entered the rate base in the 1980s. Today, there is a general reluctance on the part of both utilities and regulators to accept high "front-loaded" plant costs. Thus, low capital cost technologies, such as natural-gas-based combined cycle plants, are more in favor to meet new supply-side generation requirements.

Figure 3-3 displays a simplified schematic of the front-loading phenomenon. The utility's annual avoided cost stream, based on a low capital cost, fossil-fuel-based project, is lower in the early years but escalates as fuel prices increase over time. A levelized bid price might be higher than the utility avoided cost in the early years, even though it may fall below the levelized utility avoided cost. ${ }^{19}$ This annual cost differential represents an overpayment exposure to ratepayers in the early years of the project operation. That is, there is a risk of overpayment if the project fails to operate in the future to pay back the ratepayer "loan" it has received because of the higher than avoided cost payments in the early years. Most utility RFPs address this issue by requiring some type of financial security from the project developer. In the extreme, the utility may require a lien on the project to protect against default.

Although safeguards can be adopted, the majority of bidding RFPs penalize front-loaded payment schedules, ${ }^{20}$ in effect requiring greater compensation from the developer in other areas of the project bid. Often, the magnitude of the penalty can be reduced by providing increasing levels of security. Even in Maine, where renewables have made the biggest inroads under bidding, projects bid with front-loaded price schedules are penalized relative to non-front-loaded offers. Clearly, in such circumstances, renewables projects can be disadvantaged.

\footnotetext{
${ }^{19}$ Presumably, a utility will only select a project bid with a levelized cost below that of the utility's avoided cost unit. An exception may occur when nonprice considerations, such as environmental or fuel diversity benefits, may argue for a higher payment.

${ }^{20}$ See J. Pace, "Competitive Procurement of Generation Capacity: Beginning a New Decade," National Economic Research Associates, March 15, 1990.
} 


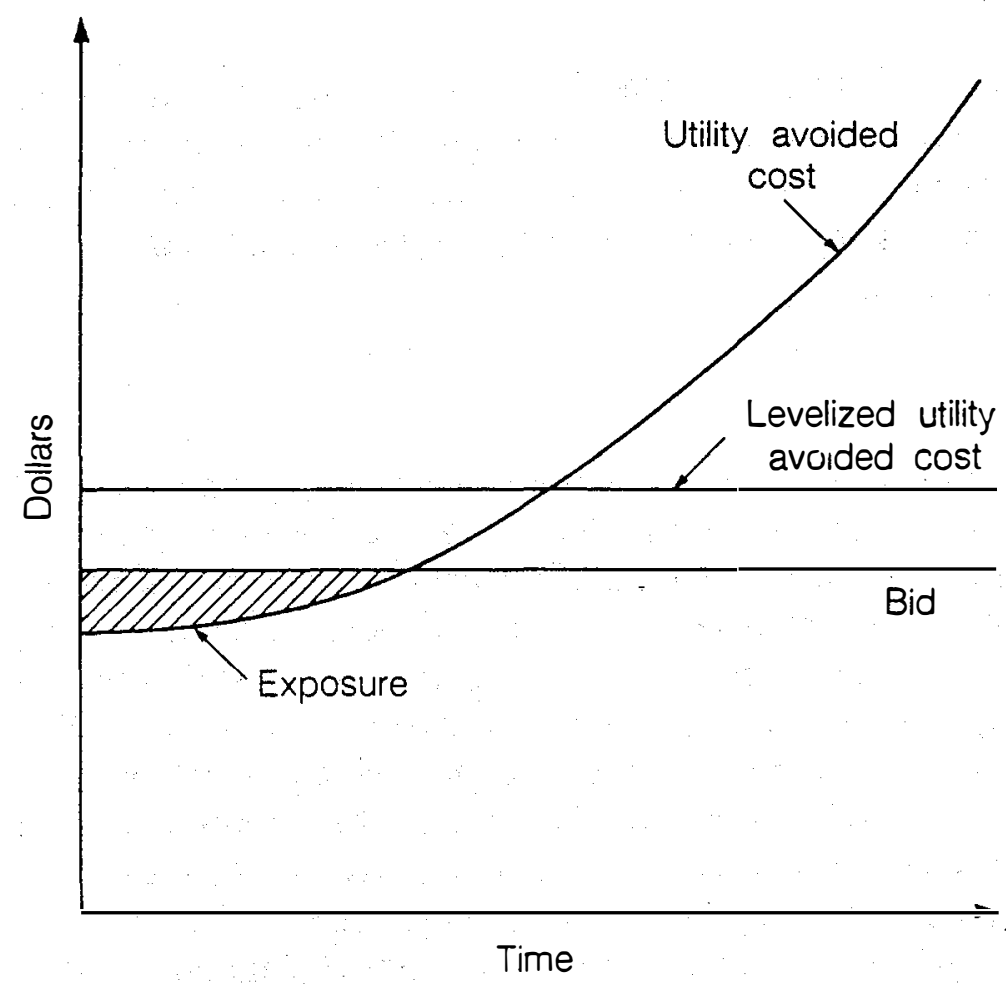

Source: E. Kahn, et al., Evaluation Methods in Competitive Bidding for Electric Power, Lawrence Berkeley Laboratory, LBL-26924, June 1989.

Figure 3-3. Ratepayer exposure from front-loaded contracts

The case for assuming the front-loading risks of RET projects has not been well articulated. First, the magnitude of any rate shock resulting from investments in renewables can be lowered since these technologies tend to be inherently modular. This modularity, in tum, offers particular benefits in the resource planning process because RETs can be deployed in smaller sizes and more rapidly to better match incremental load growth. Second, renewables may also offer nonprice benefits and values that can help compensate ratepayers for this initial risk. (See the discussion under "Other Nonprice Factors" in this section).

Finally, selection of a front-loaded RET project over a fossil-fuel-based system (with equivalent levelized costs), all other things equal, would in part internalize the risk surrounding future fossil fuel price escalation. Similar to front-loading, the risk of fuel price escalation, for utility and nonutility plants alike, is generally bome by the ratepayer through the ability of utilities to pass through these costs under fuel adjustment clauses. For example, one examination of nonutility power contracts has noted that many utility contracts with fossil-fuel-based projects, particularly natural gas, contain fuel price escalation formulas as well as clauses that allow for future renegotiation of fuel prices. ${ }^{21}$

\footnotetext{
${ }^{21}$ See E. Kahn, Risk Allocation in Independent Power Contracts, Lawrence Berkeley Laboratory, LBL-30065, April 1991.
} 


\section{Contracting}

From a project finance standpoint, the length of the power purchase contract is an important issue for RET projects. As just mentioned, most RET projects incur a greater fraction of their costs in terms of initial capital investment. Thus, a sufficiently long contract period is important to amortize these costs and avoid heavy front-end cost loading. Utilities generally offer contract terms of 20 or more years for bid winners, although some contract offers have been shorter. One analysis of bidding programs concluded that utilities prefer longer term contracts, presumably because they value the greater planning certainty that accompanies these longer term commitments. $^{22}$ On the other hand, evidence is developing that utilities will become more reluctant to commit to long-term power contracts because of market risks. ${ }^{23}$

Also important is a commitment by the utility to select and contract with winners from the solicitation if the proposals are cost effective. Several bidding solicitations have been used by utilities to compare proposed projects against the utility build option or against traditional suppliers, with all proposals eventually rejected. Many public power solicitations, in particular, have had this characteristic. ${ }^{24}$

\section{Dispatchability}

One very important requirement of most bidding RFPs is that the utility have some degree of control, or dispatch, over the output of the proposed plant. Traditionally, utilities have been required to accept nonutility generation whenever it is provided. At low loads, a utility with a significant fraction of "must take" nonutility generation must compensate for this power by reducing the output of its own plants. Utilities have argued that this situation causes inordinate wear on its plants and is economically inefficient in the dispatch of system generation. ${ }^{25}$

Utility dispatch requirements can potentially jeopardize the viability of renewable energy projects. First, utility dispatch may reduce the financial attractiveness of capital intensive RET projects if the developer is not compensated for utility-induced reductions in power output. Since variable costs are low, a renewables developer has a financial incentive to maximize plant operation to spread fixed costs. Second, projects utilizing intermittent resources, such as solar and wind energy, are inherently nondispatchable without storage, fuel augmentation, or oversizing. Making these projects dispatchable can add significantly to project costs, although it might prove cost

${ }^{22}$ See J. Pace, Supra Note 20.

${ }^{23}$ Personal communication with M. Hachey, Manager, Independent Power Projects, New England Power Service Company, February 23, 1993.

${ }^{24} \mathrm{R}$. Sherman, Jr., et al., Competing for Power: A Survey on Competitive Procurement Systems and Blueprint for the Future, National Independent Energy Producers, July 1991.

${ }^{25}$ See S. Nola and F. Sioshansi, Supra Note 4. 
effective if the on-peak to off-peak payment differential is large enough. ${ }^{26}$

One way to reduce the potential cost penalty that developers face with utility dispatch is with a fixed capacity payment, irrespective of plant output. That is, some portion of a project's value is attributable to its ability to provide capacity to the utility on notice, similar to a utility's investment in peaking turbines. ${ }^{27}$ The California Public Utilities Commission has adopted this pricing approach in its bidding order. As for firming intermittent resources, it is generally accepted that intermittents do not pose serious operating issues for utilities until their combined penetration reaches $5 \%$ to $15 \%$ or more of system capacity. ${ }^{28}$

\section{Location}

Unlike fossil fuels, many renewable energy resources cannot be easily transported in their primary form from where they naturally occur in sufficient economic concentration to where a power plant can offer the greatest operational benefit to the utility. Existing transmission capability also could lead a utility to favor particular system interconnection points. Bidding RFPs often value the locational flexibility that fuel-based projects can offer, to the detriment of many RETs. ${ }^{29}$

\section{Transmission}

When attractive renewable energy resources are remotely located from the bidding utility's territory, transmission wheeling must be arranged between utilities. More often than not, utilities offer little help in facilitating transmission, instead specifying that the developer must arrange wheeling to the soliciting utility's interconnection points. ${ }^{30}$ Notable exceptions are in Florida, Massachusetts, and New Jersey, where QF wheeling is mandatory within the state. Green Mountain Power Company (GMP), in its 1988 solicitation, offered to arrange for transmission

\footnotetext{
${ }^{26}$ Interestingly; the natural gas augmentation of the solar plants constructed by Luz International, Ltd., has actually lowered levelized generation costs by spreading the high fixed costs of the solar portion of the plant over a greater number of kilowatt-hours generated. However, this is an artifact of both the symbiosis of the solar and gas steam cycles and the wide discrepancy in costs between the solar and gas portions of the plant. With a fully mature and cost-competitive solar technology, this effect, although still important, would be reduced.

${ }^{27}$ Note, however, that the capacity payment might vary depending on the capacity value of a project to the utility.

${ }^{28}$ B. Swezey, et al., Near Term Market Assessment of Wind Energy in New England and California/Southern Nevada, A Report to the Air and Energy Policy Division, Office of Policy, Planning and Evaluation, U.S. Environmental Protection Agency, National Renewable Energy Laboratory, Review Draft, October 1991.

${ }^{29}$ While this is particularly true for bulk-power-oriented renewables projects, there is growing awareness that smaller scale applications of renewables may yield significant distributed (locational) benefits in overloaded transmission and distribution systems. See for example, D. Shugar, "Photovoltaics in the Utility Distribution System: The Evaluation of System and Distributed Benefits," Proceedings of the 21st IEEE Photovoltaic Specialists Conference, May 20, 1990.

${ }^{30}$ The Energy Policy Act of 1992 amended the Federal Power Act to allow any wholesale generator to petition the Federal Energy Regulatory Commission (FERC) for a transmission order subject to several conditions. Still to be resolved, however, is the pricing of utility transmission services.
} 
to GMP interconnection points for all successful bidders offering projects located outside the GMP service territory, subject to the costs involved. And Virginia Power has offered to wheel power for losing bidders to another interconnected utility for a fee.

\section{Other Nonprice Factors}

There are a host of other "nonprice" factors that can affect project evaluation and scoring. These factors, when included, generally recognize specific nonmarket-related attributes of energy resources and technologies, such as environmental attractiveness, fuel diversity, and localized economic benefits.

Very few states have actually incorporated environmental attributes directly into the bidding evaluation process. When these attributes are considered, they are usually combined with other nonprice factors without an explicit weighting. Notable exceptions are Massachusetts and New York, where explicit values for environmental mitigation have been developed.

In New York, the environmental values, which total $1.4 \varnothing / \mathrm{kWh}$ for a coal plant meeting federal new source performance standards (NSPS), are given a scoring weight in relation to the utility's avoided cost. The score for environmental factors may represent up to $15 \%$ of the total points available in the utility project scoring procedure and an even higher percentage in terms of bid price adjustment. ${ }^{31}$

Results from the first round of bidding in New York indicate that the consideration of environmental attributes has had the general effect of favoring the selection of natural-gas-based projects over coal-fired projects. Out of nearly $1000 \mathrm{MW}$ of winning projects, only one RET project, a 17.7-MW waste-wood-fired plant, was selected. These results have raised questions regarding the interplay of environmental and fuel diversity considerations in the bidding process; primarily, that the weights placed on these values were not large enough to overcome the penalties associated with traditional price and operational evaluation criteria. ${ }^{32}$

The Boston Edison Company (BECO) was the first Massachusetts utility to release an RFP after the Department of Public Utilities (DPU) required utilities to incorporate monetary values for environmental externalities into the bidding process. Based on the air emissions values set by the DPU, the weighted externality cost of the BECO avoided unit (a 306-MW, natural-gas-fired combined cycle unit with a 1994 in-service date) is $1.33 \phi / \mathrm{kWh}$, while the weighted average externality cost of the marginal (existing) BECO unit prior to 1994 is $3.19 \notin / \mathrm{kWh}$ (both in 1989 dollars). BECO (and later Eastern Edison) ultimately selected a block of capacity from a naturalgas-fired cogeneration project.

\footnotetext{
${ }^{31}$ Personal communication with R. Putnam, Manager, Supply-Side Planning, Niagara Mohawk Power Corporation, July 26, 1993.

${ }^{32}$ New York State Energy Office, Department of Public Service, Department of Environmental Conservation, Draft New York State Energy Plan: 1991 Biennial Update, Volume III, Issue Reports, Staff Report, Issue 7: Competitive Bidding, July 1991 (joint report).
} 
Fuel preferences have been stated in a number of RFPs. Normally, these take the form of preferences for solid fuels (e.g., coal and waste fuels), having an assumed greater long-term price stability, over petroleum fuels and even natural gas in some cases. For example, Florida Power and Light's (FP\&L) 1989 RFP stressed that petroleum fuels would not be considered and declared a preference for coal or alternative fuels. No RETs were bid. FP\&L eventually rejected all bids in favor of purchasing a 646-MW coal unit from a neighboring utility. In its 1991 RFP, Delmarva Power favored solid fuels, penalizing oil- and gas-based bids because of their price instability. Delmarva selected two projects buming petroleum coke, a refinery waste by-product.

At the same time, renewables preferences have been specified in a handful of RFPs. The second RFP from Puget Sound Power \& Light (1991) expressed a preference for renewables, as well as conservation, because of lower environmental impacts. Puget applied a 10\% price credit to these projects in the bid evaluation based on the $10 \%$ credit for conservation resources contained in the Pacific Northwest Electric Power Planning and Conservation Act. Almost 50\% of the capacity selected through this solicitation was renewables based.

The Sacramento Municipal Utility District (SMUD), in its 1990 RFP, considered environmental impacts but also explicitly recognized the value of fuel and resource diversity. Although much of the capacity selected was natural-gas-based, SMUD did select a 50-MW wind project and committed to a 350 to $400 \mathrm{MW}$ block of capacity from renewable resources and other advanced technologies (e.g., fuel cells) by 2000 to be procured through a separate RFP in 1996.

Finally, some RFPs have attempted to consider in-state economic development as an evaluation criterion. However, because the relative contribution of projects to economic development is difficult to quantify, these considerations have been very general. The best known example is in the Virginia Power RFPs in which a preference was stated for use of "in-state fuels." Through bidding, Virginia has selected the second highest percentage of coal (41\%), an indigenous resource, of any state. 


\section{Conclusions and Discussion}

\section{Conclusions}

This analysis of competitive bidding and renewable energy leads to the following conclusion:

On a relative basis, less renewable energy capacity is being contracted for by utilities under competitive bidding than under past methods of $Q F$ contracting.

Clearly, utility economics are changed from those of the early 1980s. Today, oil and natural gas prices are lower and are expected to escalate at slower rates in the future and, consequently, utility avoided costs also are much lower. This situation presents a more severe market test for renewables than existed during most of the 1980s. At the same time, renewable energy technology cost and performance has improved but, in some cases, not enough to compensate for the drop in both current and projected fossil energy prices.

Even in this more competitive environment, some RET projects have been successful, particularly when renewable energy resources are abundant and strategically located within the soliciting utility's service territory. Most successful in this regard have been wood, municipal solid waste, and geothermal projects. Nevertheless, these successes are tempered by the lack of bidding success of many other RET-based projects.

We have identified a number of areas in which the design and implementation of bidding RFPs often fail to recognize or account for many important characteristics of renewable-energy-based projects. Among these are the following:

- Duty Cycle

Renewable energy projects compete best in solicitations that seek base load power resources and compete poorly when peaking resources are requested.

\section{- Time Frame}

Because of their modularity and short lead times, renewables projects should compete well in quick start solicitations. However, to date, these solicitations have focused on the acquisition of peaking resources. On the other hand, longer term start dates allow renewables developers to incorporate expected technology and cost improvements into the bid, and conduct more extensive resource confirmation activities.

\section{- Solicitation Size}

Renewables tend to compete more effectively against fossil fuel projects in smaller sized solicitations because of the more favorable economics of RETs at smaller sizes. In large capacity solicitations, the economics of larger fossil-based plants tend to dominate. 


\section{- Participation}

Renewables appear to have had the greatest success in QF-only solicitations. A smaller percentage of renewables has been selected in "all-source" solicitations.

\section{- $\quad$ Pricing Schedule}

A majority of bidding RFPs penalize front-loaded price schedules. Since many renewables projects are capital intensive, this can represent a major obstacle to RET project selection.

\section{- Contracting}

Because of the higher relative capital cost of many RET projects, it is important that the term of the power purchase contract be sufficiently long to amortize these costs. Most bidding utilities have offered contract periods of 20 years or longer, although there are indications that utilities may become more reluctant in the future to enter into long-term agreements.

\section{- Dispatchability}

Dispatchability requirements can represent a major obstacle for some RET projects, particularly those utilizing intermittent resources. Most RFPs request or otherwise value some level of utility control over project output.

\section{- Location}

Some RFPs state a preference for particular project locations because of system operation benefits. When attractive renewable resources are located remotely from utility load centers, RET projects are disadvantaged in this respect.

\section{- Transmission}

Also working against selection of more remotely located RET projects is the general lack of attention by utilities to transmission needs. Most RFPs require the developer to arrange transmission from other utilities to points of interconnection.

\section{- Other Nonprice Factors}

Consideration of other nonprice factors, such as environmental externalities, fuel diversity, and economic development tend to benefit renewables, but to date, the positive weighting of these factors has been insufficient to overcome the net negative impacts of many of the other selection criteria outlined previously. 


\section{Discussion}

Competitive bidding is rapidly developing into a preferred mechanism for allocating and pricing utility purchases from nonutility generators. The introduction of greater competition into the procurement of new generation sources is not in itself detrimental to the greater deployment of renewable energy systems. However, states and utilities must take care to design and implement bidding systems that recognize and evaluate the entire spectrum of resource and technology attributes and planning factors, both price and nonprice related.

To date, competitive bidding solicitations have emphasized price and operational considerations over other project attributes such as environmental and fuel diversity values. Bidding procurements that only value the established characteristics of traditional generation sources and do not recognize the special characteristics and attributes of renewables will continue to result in the procurement of fewer RET projects over time. In New York, for example, it has been determined that although the bidding process valued environmental attributes, price stability, and fuel diversity, the weights placed on these values were not large enough to overcome the penalties associated with price, price pattern, and operational characteristics, such as dispatchability, with respect to prospective renewable energy projects. ${ }^{33}$

The challenge for the renewables industry is to assure that bidding approaches are developed that can fully account for all of the costs and benefits of various generation options but also recognize the special characteristics and operational limitations of renewables projects. Several recent allsource utility solicitations suggest themselves as potential models.

The first is the recent solicitation by the Sacramento Municipal Utility District (SMUD). SMUD initiated an all-source procurement process in 1990 to secure short-term and long-term energy supplies to meet future load growth and to replace both expiring utility power purchase contracts and the power lost by the closure of the Rancho Seco nuclear plant. Although the SMUD RFP stressed price, dispatchability, and locational factors, it also recognized the need for fuel and resource diversity and the need to account for environmental factors. In the RFP, SMUD also expressed a willingness to finance projects to take advantage of lower cost public financing mechanisms. ${ }^{34}$

SMUD held a public workshop on its resource evaluation process at which "the public expressed a preference for future resources that are nonfossil-fired or renewable." SMUD also developed several scenarios that helped assess both the attributes and drawbacks of different resource portfolios. ${ }^{35}$ Finally, SMUD offered to arrange wheeling when necessary to secure the most attractive resources.

As a result of the public input and staff analysis, the SMUD Board of Directors approved a

\footnotetext{
${ }^{33}$ New York State Energy Office, et al., ibid.

${ }^{34}$ Sacramento Municipal Utility District, Request for Proposals for Power Resources, March 15, 1990.

${ }^{35}$ Sacramento Municipal Utility District, Final Contenders in SMUD's Request for Power Proposals, March 1, 1991.
} 
procurement plan for $837 \mathrm{MW}$ of resources, including a 50-MW wind plant, and recommended that a 350 to $400 \mathrm{MW}$ block of power needed in 2000 be set aside for a 1996 procurement of renewables and other advanced generation technologies. ${ }^{36}$ The SMUD procurement recommendations recognize that a diversified resource mix can provide broad system benefits. For instance, SMUD will rely on gas-fired cogeneration to provide utility-specific locational benefits, while renewables will provide environmental and fuel diversity benefits.

A second model is provided by Puget Sound Power \& Light Company, which also recently completed a long-term resource solicitation. The Puget solicitation had the following characteristics:

- $\quad$ Smaller scale projects $(<70 \mathrm{MW})$ were preferred

- $\quad$ Price was compared on the basis of net present value

- $\quad$ Front-loading was acceptable given adequate security collateral

- A $10 \%$ price credit was given to renewables (and conservation)

- $\quad$ Environmental impacts were considered

- Dispatchability was encouraged but not required.

Out of 121.2 MW of capacity awarded, Puget selected $58 \mathrm{MW}$ of renewables, including projects utilizing wood liquor, landfill gas, municipal solid waste, hydro, and wind resources. ${ }^{37}$ All of these projects offered prices lower than Puget's avoided cost. ${ }^{38}$

Finally, renewable energy set-asides offer another alternative. In such a program, a block of capacity is established for which only renewables are eligible to compete. This approach assures the recognition of renewables-specific resource and project attributes but also retains the competitive benefits of traditional bidding schemes. A precedent for bidding set-asides has been established by utilities that have held separate supply-side and demand-side auctions because of the difficulty of comparing these different types of resources in a competitive framework. Renewable energy set-aside programs have already been initiated in California and New York. ${ }^{39}$

Two utilities have already pursued renewables-only auctions in order to better assess the value and potential of renewable energy in their region. In late-1991, the New England Power Company issued a renewables-only RFP, stating the intent of placing "a limited number of

\footnotetext{
${ }^{36}$ Sacramento Municipal Utility District, SMUD Board Policy Committee Report and Recommendations on SMUD Power Systems Additions, Volume II, December 16, 1991.

${ }^{37}$ Puget Sound Power \& Light Company, Request for Proposals: Long-Term Purchase of Resources from Conservation and Generation Facilities, Issued September 1991 and "Preliminary Award Group Announced," News Release, April 8, 1992.

${ }^{38}$ California Energy Markets, April 10, 1992, p. 7.

${ }^{39}$ See California Public Utilities Commission, Interim Opinion, Resource Plan Phase: Bidding for New Generation Resources, Decision 92-04-045, April 22, 1992; and New York Public Service Commission, Order Instituting Proceeding on Motion of the Commission to Examine the Plans for Implementation of Renewable Resources as Part of Meeting Future Electricity Needs in New York State, Case 92-E-0954, October 14, 1992.
} 
renewable and waste electric power production facilities into commercial operation to assess the current-day feasibility, value, resource potential, and environmental attributes of renewable resource technologies. ${ }^{140}$ And more recently, Portland General Electric issued a renewables-only RFP to "acquire a limited number of projects of diverse and proven renewable technologies ... to demonstrate the cost-effectiveness of renewable energy resources, as well as their commercial viability." ${ }^{14}$

${ }^{40}$ New England Power Company, "Notice of Intent: Small Power Producer Request for Proposals," 1991.

${ }^{41}$ Portland General Electric, Request for Power Supply Proposals: Renewable Resource Technologies, June 1993. 


\section{Appendix}

\section{State by State Review of Competitive Bidding Results}




\section{Table of Contents}

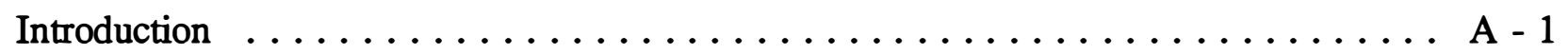

California .......................... -3

Delaware/Maryland ......................... A -6

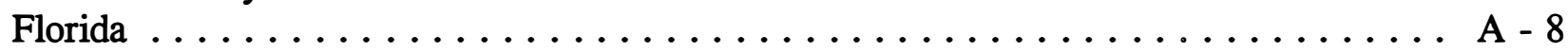

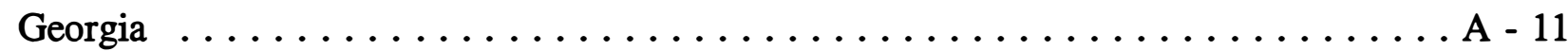

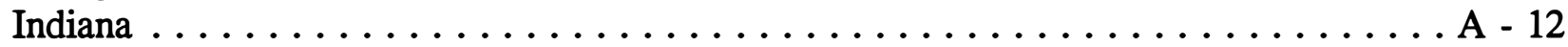

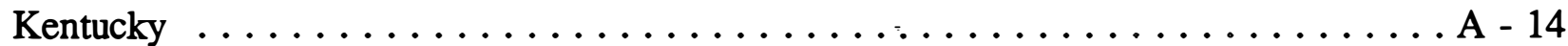

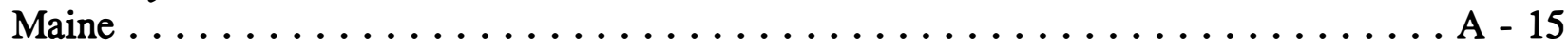

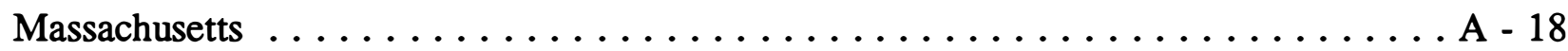

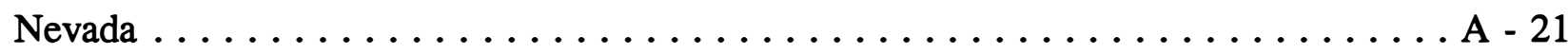

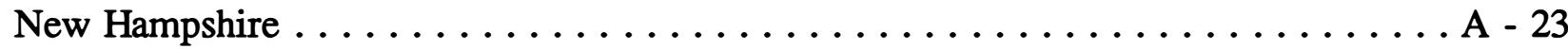

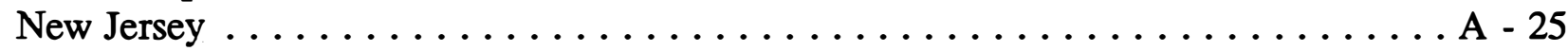

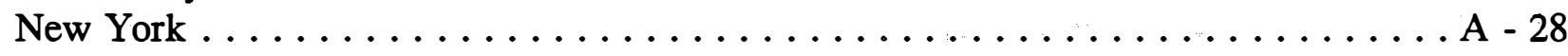

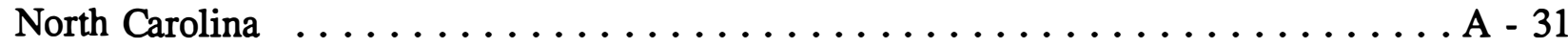

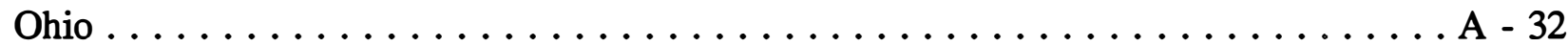

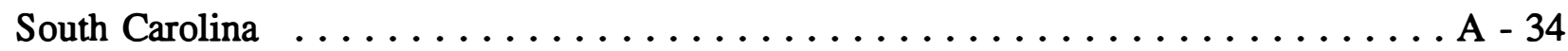

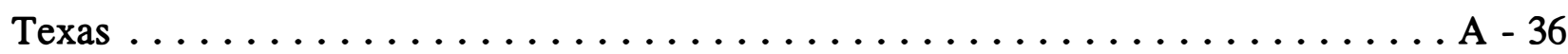

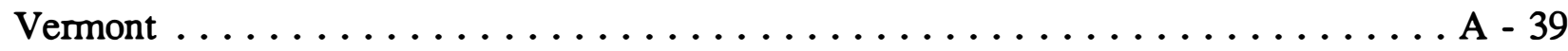

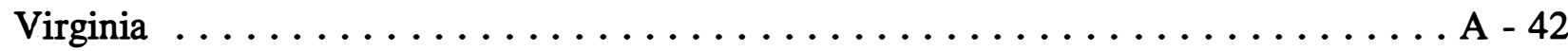

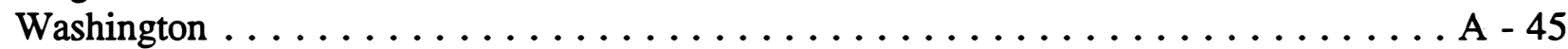

Bonneville Power Administration . . . . . . . . . . . . . . . . A - 49

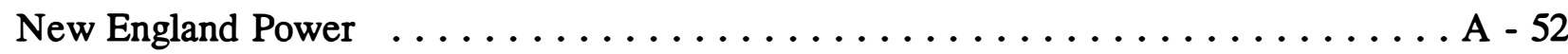

PacifiCorp ............................ 54 


\section{Introduction}

This appendix reviews the status of competitive bidding in those states in which bidding solicitations had been held and final results had been announced by the end of 1992 . The states and solicitations included are limited to supply-side requests for proposals (RFPs) that were open to all fuel and technology types. Thus, for example, the state of Colorado is not included because only demand-side solicitations have been held, and the state of Hawaii is not included because its two supply-side solicitations specified either a particular resource (geothermal) or plant type (bidding to build a pre-specified project).

The state write-ups review: (1) regulatory actions on bidding; (2) bidding status, in terms of the utilities that have conducted bidding and the results achieved; and (3) the author's interpretation of the impact of the bidding process on renewables. In addition, separate sections are provided for three multistate entities: the Bonneville Power Administration, the New England Power Company, and PacifiCorp. Figure A-1 graphically summarizes the total capacity acquired through bidding in the different states and by the multistate utilities.

Figure $A-1$

Capacity Selected Through Bidding

(By State)

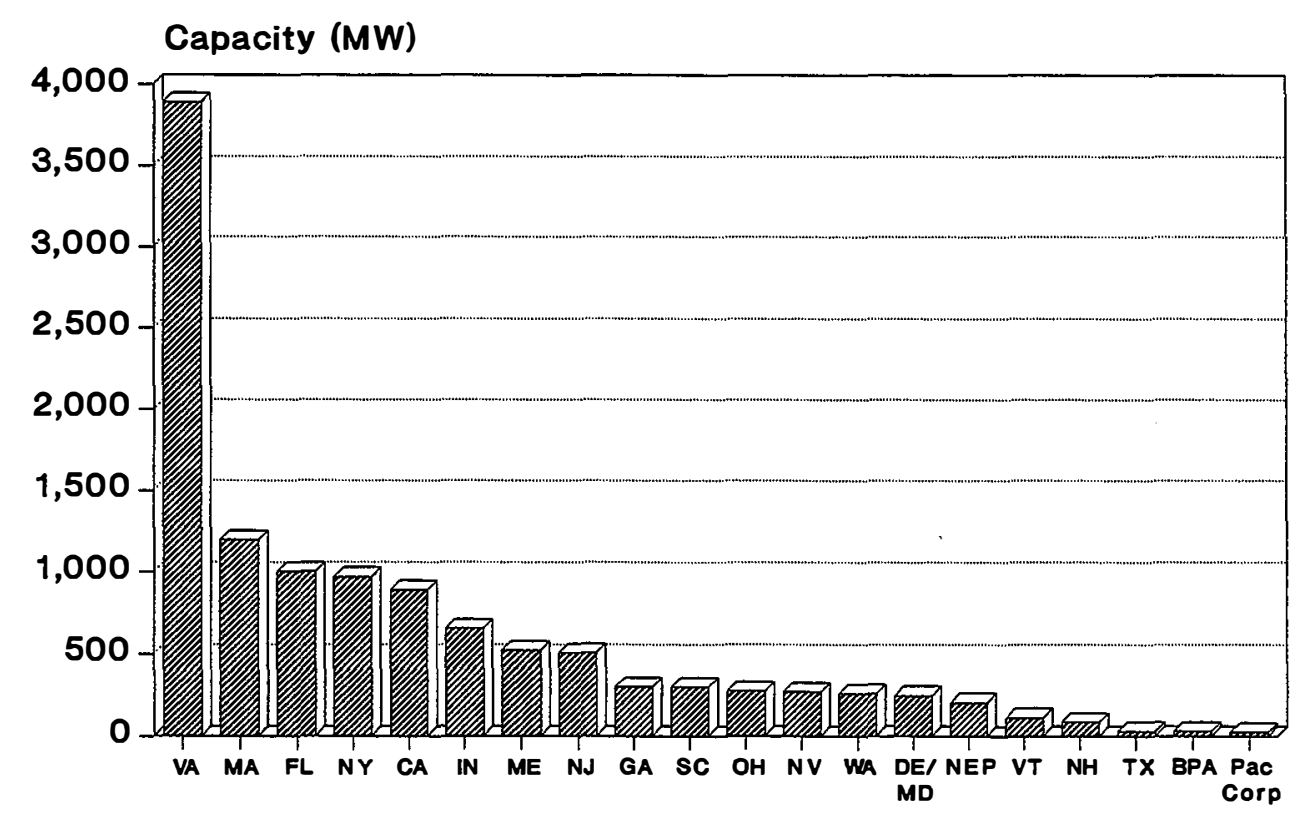

Note: Excludes technology-specific and DSM-only RFPs 
The information contained in this appendix was gleaned from many sources. Primary information sources include

- Discussions with and materials (including RFPs and press releases) provided by electric utility company personnel and state utility regulatory staff.

- Robertson's Current Competition and other information provided by Hope Robertson.

- $\quad$ Several industry newsletters published by the McGraw-Hill Company, including Electric Utility Week, Independent Power Report, Independent Power Report Quarterly, and Northeast Power Report.

- California Energy Markets, published by NewsData Corporation.

However, the interpretation of this information and data, as presented in the following sections, is the sole responsibility of the author. 


\section{California}

\section{Regulatory Actions}

In 1992, the Public Utilities Commission (PUC) issued an order requiring bidding for new resources by the state's investor-owned utilities (IOUs) to supply a portion of forecasted utility capacity needs. ${ }^{1}$ Important elements of this decision are: participation is limited to QFs; standard offer contracts will be offered to winners based on a utility's long-run marginal costs, including both fixed and variable components (a fixed capacity price makes utility dispatch through curtailment less of an economic issue for project developers); levelized payments are allowed over a 30-year contract period; the biddable capacity need was identified for each utility; the costs of residual air emissions are explicitly valued; and a set-aside for renewables was established in lieu of using a fuel diversity value. A state law, which took effect in 1992, requires a set-aside for renewables if both environmental and diversity costs are not included in the bid evaluation criteria.

\section{Bidding Status}

To date, only public utility entities have conducted bidding. ${ }^{2}$ IOUs will be subject to bidding under the recent PUC rulemaking.

\begin{tabular}{||l|c|c|c|c||}
\hline \hline Utility & Year & $\begin{array}{c}\text { Requested } \\
(\mathbf{M W})\end{array}$ & $\begin{array}{c}\text { Total Selected } \\
(\mathbf{M W})\end{array}$ & $\begin{array}{c}\text { RE Selected } \\
(\mathbf{M W})\end{array}$ \\
\hline \hline NCPA \#1 & 1989 & $40-330$ & 50 & 0 \\
\hline \hline LADWP & 1990. & 600 & Suspended & $\ldots$ \\
\hline SMUD & 1990 & $>1000$ & 837 & $50(6 \%)$ \\
\hline NCPA \#2 & 1991 & 200 & Pending & $-\cdots$ \\
\hline
\end{tabular}

Note: Supply-side bidding only

\section{Impact on Renewables}

Significant amounts of renewables capacity have been bid in the public power auctions. The Northern California Power Agency (NCPA)-a joint powers agency serving 11 cities, a

\footnotetext{
${ }^{1}$ California Public Utilities Commission, Interim Opinion, Resource Plan Phase: Bidding for New Generation Resources, Decision 92-04-045, April 22, 1992.

${ }^{2}$ The exception is San Diego Gas and Electric which issued two RFPs in 1992; the first to compare against near term utility capacity purchases and the second to compare against a utility repowering option. These solicitations are distinct from the statewide bidding process discussed in this section.
}

$$
\text { A }-3
$$


cooperative, and an irrigation district—passed over renewables in its 1989 all-source solicitation for long-term power supplies, opting for $50 \mathrm{MW}$ of system sales from a Northwest utility. Very little evaluation information was provided in the RFP. In addition to price, NCPA stated that it would evaluate "the ability of NCPA to schedule power deliveries, the point of interconnection with NCPA's or some other utility's transmission system, and the likelihood that the project will come on-line and continue to provide energy and capacity for the term of the contract." Renewables made up about one-half of the $3580 \mathrm{MW}$ of capacity proposals received. Later analysis revealed that factors working against renewables were a primary emphasis on price, an aversion to front-load pricing, and a preference for dispatchability. Also, the all-source nature of the participation was a contributing factor in the final selection.

NCPA released a second RFP in 1991 for $340 \mathrm{MW}$ of resources for the year 2000. In this RFP, NCPA noted the same general criteria for evaluation, as well as "'societal cost' testing of resources that may increase emissions of pollutants." In addition, a table of evaluation factors was provided, although no weighting of these factors was revealed. The primary attributes to be considered were price (delivered), price structure, project viability, transmission, operating characteristics, environmental effects, and diversity. A final negotiation group has not been announced. However, from 10,000 MW of proposals received, NCPA has short listed $1639 \mathrm{MW}$ of resources: $1120 \mathrm{MW}$ from natural gas (68\%); $305 \mathrm{MW}$ from coal (19\%); $111 \mathrm{MW}$ from hydro (7\%); $65 \mathrm{MW}$ from system sales (4\%); and $38 \mathrm{MW}$ from demand-side management (2\%). Although proposals were submitted for wind, geothermal, and biomass projects, none of these made the short list.

After "short listing" several renewables project proposals received from a 600-MW all-source RFP for the 1996-2000 time frame, the Los Angeles Department of Water and Power (LADWP) suspended its process, seeking instead to pursue demand-side opportunities as well as the development of LADWP-owned geothermal leases and negotiations for non-utility cogeneration facilities outside of the bidding process. "LADWP received $4085 \mathrm{MW}$ of proposals, of which 1263 MW (31\%) were renewables based.

The Sacramento Municipal Utility District (SMUD) recently completed an all-source procurement. Initiated in 1990, SMUD sought to secure short-term and long-term energy supplies to meet future load growth and to replace both expiring utility power purchase contracts and the power lost by the closure of the Rancho Seco nuclear plant. The SMUD RFP stressed price, dispatchability, and locational factors, but also recognized the value of fuel and resource diversity and considered environmental impacts. SMUD also expressed a willingness to finance projects to take advantage of lower cost public financing mechanisms.

After a long process that involved an unprecedented level of public participation, the SMUD Board of Directors approved selection of five local gas-fired cogeneration projects, totaling 607 MW, a 130-MW gas-fired plant at a compressor station in British Columbia, $50 \mathrm{MW}$ of Canadian power imports, and a 50-MW wind farm. The SMUD board also committed to a 350-400 MW block of capacity from advanced technologies (e.g., fuel cells) and renewable resources by 2000 to be procured through a separate RFP in 1996. 


\section{CA - Bidding Winners by Fuel Type}

(887 MW)

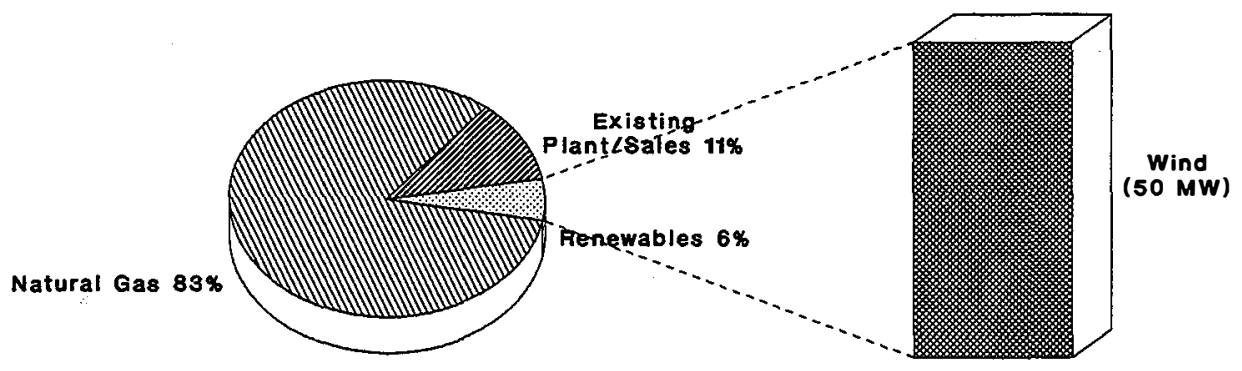

Renewables represent only $6 \%$ of the total capacity procured in California through bidding, which seems surprising given the state's renewable resource base and its history of renewable energy development. However, bidding to date has been limited to public utility entities that (with the exception of SMUD) have focused on price-related factors. The recent PUC order on bidding for the state's IOUs should promote a greater level of renewables selection because both the bid evaluation criteria and standard offer contract features recognize and address some of the special needs of renewables projects. Furthermore, 20\% (297.5 MW) of the 1451.5 MW of need established in the order will be reserved for renewables. 


\section{Delaware/Maryland}

\section{Regulatory Actions}

No formal bidding rules have been adopted by either state. The Maryland Public Service Commission (PSC) agreed to allow the 1991 Delmarva Power \& Light RFP after several concerns regarding potential utility self-dealing were resolved to the commission's satisfaction. The Delaware PSC neither approved nor opposed the Delmarva solicitation. In 1992, the Maryland PSC ruled that Baltimore Gas \& Electric must put out to bid a portion of the $800 \mathrm{MW}$ that the utility wants to build.

\section{Bidding Status}

Delmarva Power and Light, which operates in Delaware, Maryland, and Virginia, is the only utility to conduct bidding in either Delaware or Maryland.

\begin{tabular}{||l|c|c|c|c||}
\hline \hline Utility & Year & $\begin{array}{c}\text { Requested } \\
\text { (MW) }\end{array}$ & $\begin{array}{c}\text { Total Selected } \\
(\mathbf{M W})\end{array}$ & $\begin{array}{c}\text { RE Selected } \\
\text { (MW) }\end{array}$ \\
\hline \hline Delmarva \#1 & 1989 & 100 & 48 & 0 \\
\hline Delmarva \#2 & 1991 & 150 & 198 & 0 \\
\hline
\end{tabular}

\section{Impact on Renewables}

Delmarva's initial solicitation (1989) was for $100 \mathrm{MW}$ of peaking capacity to be available in 1992. Delmarva used a scoring system weighted $60 \%$ to price and $40 \%$ to nonprice factors. The utility compared bid prices to a gas turbine proxy unit. Both economic and operational dispatch were emphasized in the RFP. Delmarva selected an existing 48-MW refinery gas plant as the sole winning proposal. The plant has been owned and operated by Delmarva since the 1950s but will be purchased and operated by the refiner. The plant will be dispatchable by Delmarva.

In 1991, Delmarva released an all-source RFP for $150 \mathrm{MW}$ of base load and intermediate generation for the 1995-1997 time frame. Delmarva again used a 60\%/40\%, price/nonprice weighting scheme to evaluate the proposals. While the nonprice component focused on project viability factors, nonprice considerations also included environmental permitting certainty, awarding higher scores for exceeding environmental standards ( $\pm 5 \%)$; fuel diversity, representing up to a $6 \%$ weight, giving higher scores to renewable and waste fuels because of price stability; and location $( \pm 2 \%)$. A 150 -MW natural gas combined cycle plant was used as a proxy to set the utility avoided cost ceiling. Delmarva selected two Delaware-based projects, a 165-MW petroleum coke gasification cogeneration project to be located at the same refinery that won the only contract in the 1989 RFP, and a 33-MW small power project utilizing wastepaper and petroleum coke. The petroleum coke fuel is a waste by-product from refinery operations. 


\section{DE/MD - Bidding Winners by Fuel Type \\ (246 MW)}

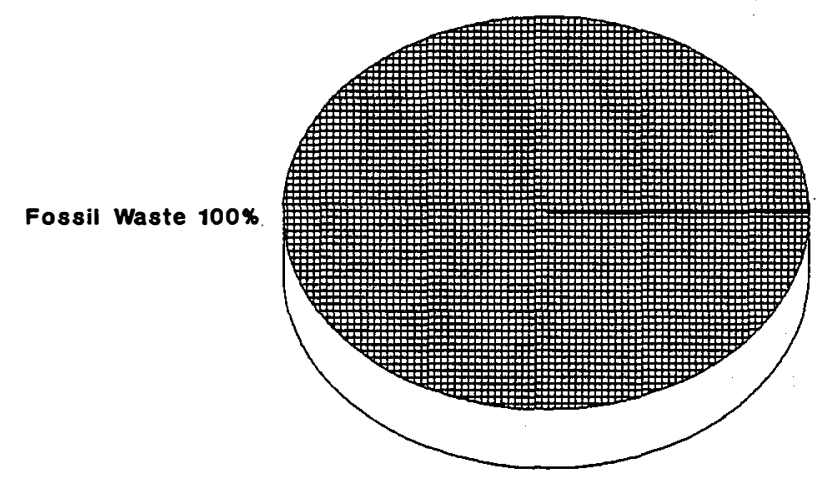

A - 7 


\section{Florida}

\section{Regulatory Actions}

No formal bidding rules have been adopted, but bidding is allowed. A statewide standard offer contracting process exists for qualifying facilities (QFs) of less than $75 \mathrm{MW}$ to obtain power purchase contracts. QFs and independent power producers (IPPs) greater than $75 \mathrm{MW}$ can negotiate contracts outside of bidding.

\section{Bidding Status}

Five bidding solicitations have been held, involving two investor-owned utilities (IOUs), one electric cooperative, and one municipal utility.

\begin{tabular}{||l|c|c|c|c||}
\hline \hline Utility & Year & $\begin{array}{c}\text { Requested } \\
\text { (MW) }\end{array}$ & $\begin{array}{c}\text { Total Selected } \\
\text { (MW) }\end{array}$ & $\begin{array}{c}\text { RE Selected } \\
\text { (MW) }\end{array}$ \\
\hline \hline Seminole Electric \#1 & 1988 & 440 & 440 & 0 \\
\hline \hline FP\&L & 1989 & 800 & Rejected & --- \\
\hline Orlando & 1990 & 440 & Rejected & -- \\
\hline Seminole Electric \#2 & 1990 & 660 & Pending & --- \\
\hline Florida Power Corp & 1991 & 400 & 559 & $79(14 \%)$ \\
\hline \hline
\end{tabular}

\section{Impact on Renewables}

The 1988 solicitation from Seminole Electric Cooperative was unusual in that it requested 440 MW of backup capacity for the potential replacement of existing contracted power. All potential sources could participate. Seminole ultimately selected a 440-MW natural gas-fired IPP project. The backup power requirement essentially restricted the response to utility-mode projects having additional outlets for power sales. In 1990, Seminole released a second RFP for 660 MW of peaking and intermediate power from 1996-2000 to compare against its own build options. Results have not been announced.

The Florida Power and Light (FP\&L) solicitation (1989) represents a more traditional utility bidding process. Proposals for all sources of capacity were requested to supply $800 \mathrm{MW}$ in the 1994-1997 time frame. FP\&L first performed an economic screening of all proposals before subjecting the proposals to a more detailed evaluation using 17 additional criteria. Among these criteria were location, fuel diversity and price risks, dispatchability, and state and community benefits. Although no explicit weighting procedure was provided for price and nonprice factors, 


\section{FL - Bidding Winners by Fuel Type}

(999 MW)

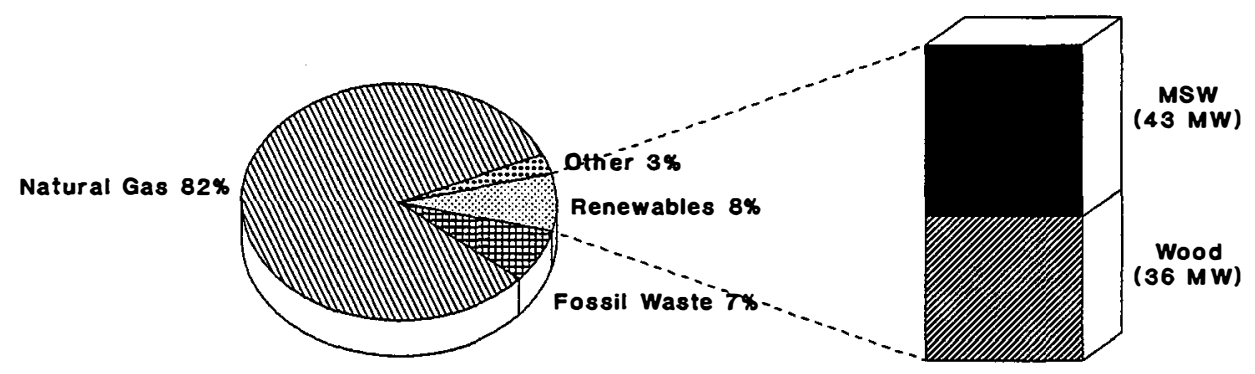

FP\&L emphasized technical factors relating to dispatchability and siting. Under fuel diversity, the FP\&L RFP stressed that petroleum-fueled projects would not be considered and declared a preference for coal or alternative fuels. Environmental considerations were subsumed under "state and community benefits" but did not receive great emphasis. FP\&L received bids totaling $10,793 \mathrm{MW}$; more than $70 \%$ were for coal projects and $27 \%$ for natural gas projects. No renewables were bid. Ultimately, FP\&L rejected all bids in favor of purchasing a 646-MW coal unit from Georgia Power Company.

In 1990, the Orlando Utilities Commission (OUC) issued an RFP for 440 MW of base load power to compare against its own build option for 1997, a 460-MW unit addition to an existing coal-fired plant. Orlando received 19 notices of intent to bid for $5590 \mathrm{MW}$ (43\% coal and $40 \%$ natural gas), including a 250-MW solar unit. Only three formal proposals, totaling $1270 \mathrm{MW}$ (two gas-fired combined cycle and one coal plant), were eventually received. Orlando rejected the three bids as more costly than its own build option.

In 1991, Florida Power Corp. issued a solicitation for $400 \mathrm{MW}$ of firm capacity to be available by the start of 1994. Bidders were given less than three weeks to respond to the RFP. Because of the early start period, existing projects or those in an advanced stage of development were given preference. Florida Power selected eight projects totaling $559 \mathrm{MW}, 68 \%$ of which represent natural gas combined cycle units. An existing 43-MW municipal solid waste plant was selected along with a 36-MW combined wood waste/tire burning plant.

Overall, renewables represent 5\% of the capacity actually selected through bidding in Florida. The reasons that renewables have fared poorly are not straightforward. Some solicitations, such

$$
\text { A }-9
$$


as the Seminole and Orlando RFPs, had very stringent cost or performance criteria. The short time frame of the Florida Power Corp. solicitation might have been detrimental to a greater renewables response, although $14 \%$ of the capacity selected was renewables based. The FP\&L solicitation, which focused on price and technical factors, received no bids from renewables. The fact that QFs can negotiate standard offer contracts outside of the bidding process may help explain the low level of renewables participation and overall selection. The existence of this alternative to bidding in Florida remains true to one of the fundamental tenets of PURPA, i.e., the provision of a guaranteed market for QF power. 


\section{Georgia}

\section{Regulatory Actions}

No formal bidding rules have been adopted.

\section{Bidding Status}

One electric cooperative has conducted a bidding solicitation.

\begin{tabular}{|l|c|c|c|c|}
\hline Utility & Year & $\begin{array}{c}\text { Requested } \\
(\mathbf{M W})\end{array}$ & $\begin{array}{c}\text { Total Selected } \\
(\mathbf{M W})\end{array}$ & $\begin{array}{c}\text { RE Selected } \\
(\mathbf{M W})\end{array}$ \\
\hline \hline Oglethorpe & 1990 & 700 & 300 & 0 \\
\hline
\end{tabular}

\section{Impact on Renewables}

In 1990, Oglethorpe Power, a generation and transmission cooperative, which supplies power to 39 Georgia distribution cooperatives, issued an RFP for $700 \mathrm{MW}$ of peaking and intermediate power-300 MW for 1993 and $400 \mathrm{MW}$ for 1996. The selection was weighted $60 \%$ price and $40 \%$ nonprice; with the nonprice components related to development and operational factors. Oglethorpe did not reveal its avoided cost. Out of $7200 \mathrm{MW}$ of responses, only two small renewables (hydro) projects were offered. Oglethorpe selected a 300-MW natural gas turbine project for further negotiations for the 1993 block and rejected all proposals for the 1996 block. In rejecting the 1996 proposals, Oglethorpe stated that none of the offers could compete with an existing wholesale power purchase arrangement with Georgia Power Company. 


\section{GA - Bidding Winners by Fuel Type \\ (300 MW)}

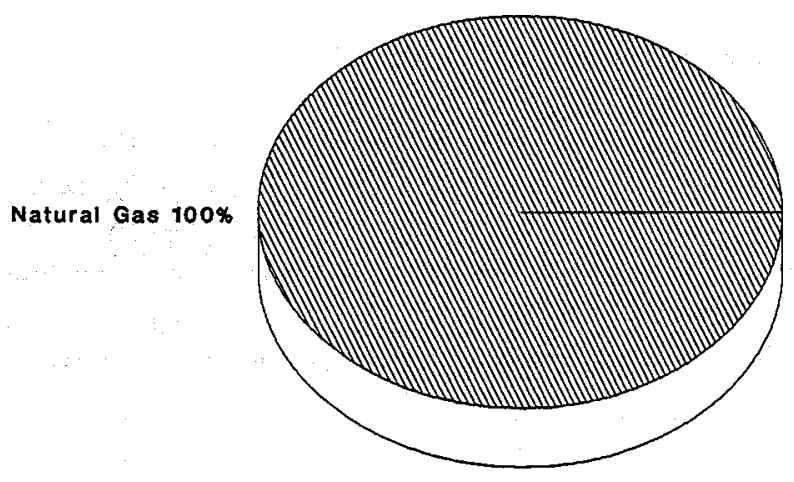

A -12 


\section{Indiana}

\section{Regulatory Actions}

No formal bidding rules have been adopted.

\section{Bidding Status}

One municipal power agency and one investor-owned utility have conducted bidding.

\begin{tabular}{||l|c|c|c|c||}
\hline \hline Utility & Year & $\begin{array}{c}\text { Requested } \\
(\mathbf{M W})\end{array}$ & $\begin{array}{c}\text { Total Selected } \\
(\mathbf{M W})\end{array}$ & $\begin{array}{c}\text { RE Selected } \\
(\mathbf{M W})\end{array}$ \\
\hline \hline IMPA & 1989 & $120-160$ & Rejected & -- \\
\hline \hline PSI & 1989 & 1300 & 655 & 0 \\
\hline \hline
\end{tabular}

\section{Impact on Renewables}

In April 1989, the Indiana Municipal Power Agency (IMPA) solicited proposals for 140 MW of peaking capacity. IMPA requested bids for two 35-MW units to be located in two different communities. IMPA rejected all bids received as not meeting the peaking specifications and as being more expensive than the utility's own build option.

In late 1989, Public Service Indiana (PȘI) released a solicitation for up to $1300 \mathrm{MW}$ of electricity resources to be delivered to the utility in annual blocks during 1993-2000. Both supply-side and demand-side resources were requested, and all sources were allowed to bid. Separate RFPs were developed for non-utility generators, demand-side management (DSM), and utility generators. The utility RFP sought firm power from pre-existing units or system sales.

In the non-utility generator RFP, PSI listed a number of price and nonprice factors as selection criteria. Among the nonprice factors were fuel type and stability/security of fuel supply; location and impact on transmission system; interconnection/wheeling considerations; and environmental benefits/considerations. However, no specific weighting of these factors was identified. Although provision was made in the RFP for cost levelization (with security) and nondispatchability, it was not clear how these characteristics would be treated in the evaluation process. PSI stressed that price was the foremost consideration and dispatchability was to be treated as a price factor.

PSI selected six gas-fired peaking units (totaling $640 \mathrm{MW}$ ) from four different projects and 15 MW of DSM-related projects. 


\section{IN - Bidding Winners by Fuel Type \\ (655 MW)}

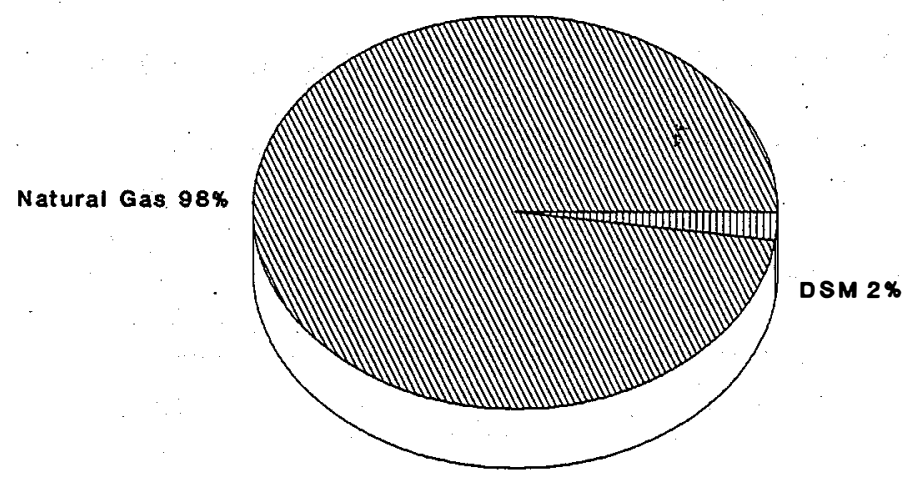

A -14 


\section{Kentucky}

\section{Regulatory Actions}

Bidding is allowed; however, no formal bidding rules have been adopted.

\section{Bidding Status}

One electric cooperative has conducted a bidding solicitation.

\begin{tabular}{|l|c|c|c|c||}
\hline \hline Utility & Year & $\begin{array}{c}\text { Requested } \\
(\mathbf{M W})\end{array}$ & $\begin{array}{c}\text { Total Selected } \\
\text { (MW) }\end{array}$ & $\begin{array}{c}\text { RE Selected } \\
\text { (MW) }\end{array}$ \\
\hline \hline East Kentucky Power & 1990 & 400 & Rejected & $\cdots$ \\
\hline
\end{tabular}

\section{Impact on Renewables}

In late 1990, East Kentucky Power Cooperative requested proposals for $400 \mathrm{MW}$ of capacity to compare to the utility's own power supply plan. The utility's need was oriented primarily toward peaking resources. Eighteen bids totaling $4601 \mathrm{MW}$ were received, primarily for peaking projects. East Kentucky's stated bid evaluation was weighted $60 \%$ for price and $40 \%$ for nonprice factors, including environmental considerations. The utility rejected all proposals as more expensive than its own combustion turbine build option. 


\section{Maine}

\section{Regulatory Actions}

In 1981, the Public Utilities Commission (PUC) issued a rule known as Chapter 36, which established the principles and procedures for setting rates for purchases of electricity from QFs under PURPA. In this rule, the PUC gave utilities the authority to negotiate contracts with QFs to satisfy block requirements, called decrements, of capacity and energy.

Although bidding has been used as a method of acquiring QF capacity since 1984, no specific bidding guidelines have been issued by the PUC. No commission preapproval or review of utility RFPs are required, thus giving the utilities considerable flexibility in designing bidding programs. While bidding was initially limited to QFs, all-source bidding was adopted in 1989.

Chapter 36 specifically allows levelized payments to producers. Payments in any given year may also exceed levelized avoided costs as long as the total life cycle levelized bid prices do not exceed the levelized utility avoided cost. The Maine Energy Policy Act, passed in 1988, requires utilities to give preference first to conservation and demand-side management and second to QFs in resource planning and procurement.

\section{Bidding Status}

All three of the state's utilities have conducted bidding solicitations.

\begin{tabular}{||l|c|c|c|c||}
\hline \hline Utility & $\begin{array}{c}\text { Year } \\
\cdots\end{array}$ & $\begin{array}{c}\text { Requested } \\
\text { (MW) }\end{array}$ & $\begin{array}{c}\text { Total Selected } \\
\text { (MW) }\end{array}$ & $\begin{array}{c}\text { RE Selected } \\
\text { (MW) }\end{array}$ \\
\hline \hline Central Maine Power \#1 & 1984 & 100 & 150 & $150(100 \%)$ \\
\hline \hline Central Maine Power \#2 & 1984 & 100 & 153 & $153(100 \%)$ \\
\hline \hline Central Maine Power \#3 & 1987 & 100 & 128 & $128(100 \%)$ \\
\hline Central Maine Power \#4 & 1987 & 100 & 18 & 0 \\
\hline Central Maine Power \#5 & 1989 & 700 & 69 & $65(94 \%)$ \\
\hline Bangor Hydro-Electric & 1989 & 60 & Suspended & --- \\
\hline Maine Public Service & 1990 & Open & Rejected & --- \\
\hline \hline
\end{tabular}

\section{Impact on Renewables}

To date, Central Maine Power Company (CMP) has held several bidding solicitations for standard 50-MW decrements of capacity. As a result of these solicitations, CMP has signed contracts for nearly 60 projects with more than $500 \mathrm{MW}$ of capacity. 


\section{ME - Bidding Winners by Fuel Type}

(518 MW)

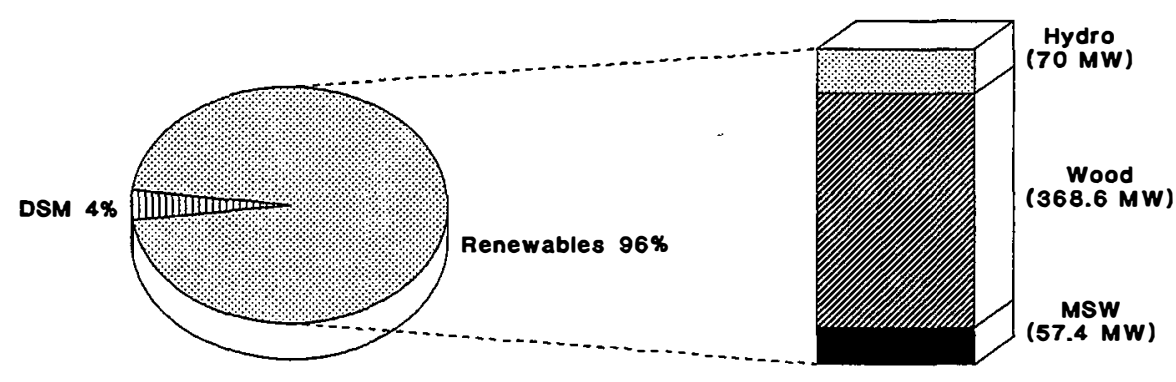

Negotiation priority was established by an overall rating index, which is the product of indexes established for capacity (which meets New England Power Pool criteria and has an 80\% on-peak capacity factor); endurance (adequate security for nonperformance); security (payment structure); price (bid price as a percentage of avoided cost); and operating (dispatch/scheduling/delivery). Bidders were given full knowledge of the scoring system, including avoided cost projections, and thus could self-score their projects. Participation in the first four solicitations (1984 and 1987) was limited to QFs, while the 1989 RFP was all-source.

In 1989, Bangor Hydro-Electric issued an all-source solicitation for $60 \mathrm{MW}$ of capacity for the 1993-1997 time frame but later suspended the process when load growth fell. Bangor received more than $1500 \mathrm{MW}$ of proposals for wood, hydro, and various fossil-fuel-fired projects. Bangor has reported that all prices bid were above the utility's avoided cost for a utility-developed project (a 38-MW hydro project). However, the utility recently has reopened negotiations with bidders.

In 1990, Maine Public Service (MPS) released an open-ended solicitation for capacity resources. The utility rejected the small number of bids received as being higher than avoided cost. MPS also lost two large customers, which negated the need for new capacity.

All of the generation resources acquired by CMP through bidding have been renewables based, primarily wood-fired cogeneration. The many wood-fired projects are associated with the plentiful wood waste resource and the well-established nature of the wood and paper products industries in the state, leading to favorable economics. The initial limitation of bidding participation to QFs was advantageous to renewables. Also, indigenous energy resource 
alternatives are limited. The Central Maine Power solicitations allowed levelized or front-loaded rates, which also help renewables. Although the Maine PUC has been active in encouraging alternatives to traditional utility central station generation, explicit consideration of environmental factors has not played a role in the bid selection process. 


\section{Massachusetts}

\section{Regulatory Actions}

In 1986, Massachusetts became the first state to establish formal bidding rules for purchases from qualifying facilities (QFs) under PURPA. Utilities must bid for capacity every two years and the block must be equal to actual projected need or 5\% of the utility's peak demand, whichever is greater. Thus, a utility might be required to solicit bids even if it has no identified need. Each utility is required to file a bidding RFP with the Department of Public Utilities (DPU). A ranking formula must be developed that incorporates, at a minimum, considerations of price and pricing formula, quality of output, timing of output, the likelihood of project success, and any "other information relevant to a qualifying facility's effect on net ratepayer benefits." Utilities are also required to wheel QF power within the state at negotiated rates. ${ }^{3}$

In a 1990 ruling, the DPU broadened the scope of the bidding criteria to include explicit consideration of environmental externalities and broadened bidding participation to include utilities and independent power producers (IPPs). Utilities are also now required to solicit bids for any resource need identified over a subsequent ten-year period. ${ }^{4}$

\section{Bidding Status}

Massachusetts has experienced the greatest activity in bidding, with eight utilities releasing 14 RFPs.

\begin{tabular}{||l|c|c|c|c||}
\hline \hline Utility & Year & $\begin{array}{c}\text { Requested } \\
\text { (MW) }\end{array}$ & $\begin{array}{c}\text { Total Selected } \\
\text { (MW) }\end{array}$ & $\begin{array}{c}\text { RE Selected } \\
\text { (MW) }\end{array}$ \\
\hline \hline Boston Edison \#1 & 1987 & 200 & 341.5 & $32.4(9 \%)$ \\
\hline \hline Eastern Edison \#1 & 1987 & 30 & 46 & $20(43 \%)$ \\
\hline Cambridge Electric \#1 & 1988 & 33 & 33 & 0 \\
\hline \hline Comm. Electric \#1 & 1988 & 76 & 102.6 & $52.6(51 \%)$ \\
\hline Fitchburg G\&E & 1988 & 11.7 & 13.5 & $13.5(100 \%)$ \\
\hline Nantucket & 1988 & 4 & None Received & $\ldots$ \\
\hline
\end{tabular}

${ }^{3}$ Massachusetts Department of Public Utilities, Rules Governing Sales of Electricity by Small Power Producers and Cogenerators to Utilities and Sales of Electricity by Utilities to Small Power Producers and Cogenerators, 220 CMR 8.00, as amended August 26, 1986.

${ }^{4}$ Massachusetts Department of Public Utilities, Rules Governing the Procedure by Which Additional Resources are Planned, Solicited, and Procured by Investor-Owned Electric Companies, 220 CMR 10.00, August 31, 1990.

$$
\text { A - } 19
$$




\begin{tabular}{|l|c|c|c|c||}
\hline \hline Utility & Year & $\begin{array}{c}\text { Requested } \\
\text { (MW) }\end{array}$ & $\begin{array}{c}\text { Total Selected } \\
\text { (MW) }\end{array}$ & $\begin{array}{c}\text { RE Selected } \\
\text { (MW) }\end{array}$ \\
\hline \hline Boston Edison \#2 & 1989 & 200 & 200 & 0 \\
\hline Eastern Edison \#2 & 1989 & 30 & 30 & $30(100 \%)$ \\
\hline Western Mass. Electric & 1989 & 54 & 72 & $18(25 \%)$ \\
\hline Cambridge Electric \#2 & 1990 & 28 & 23 & 0 \\
\hline Comm. Electric \#2 & 1990 & 88 & 93.5 & $18.5(20 \%)$ \\
\hline Boston Edison \#3 & 1991 & 132 & 170 & 0 \\
\hline Eastern Edison \#3 & 1992 & 43.6 & 70.6 & 0 \\
\hline Massachusetts Electric & 1992 & $200^{*}$ & Pending & -- \\
\hline \hline
\end{tabular}

"Contingency RFP

\section{Impact on Renewables}

A full delineation of the individual utility bidding processes in Massachusetts is beyond the scope of this study. However, one important trend can be noted based on data contained in studies conducted by the Massachusetts Electric Company (MECO). Before bidding was instituted in $1986,38 \%$ of the $863.5 \mathrm{MW}$ of non-utility-owned capacity contracted for by the state's utilities was renewables based (hydro and municipal solid waste [MSW]). Only 15\% of the capacity contracted for through bidding is renewables based (wood and MSW). An analysis of the evaluation used by Boston Edison (BECO) in its second RFP, performed by Lawrence Berkeley Laboratory, noted that the BECO evaluation criteria contained "very heavy penalties for frontloading." ${ }^{15}$ BECO ultimately selected 100-MW blocks of capacity from two large gas cogeneration projects. Several renewable energy projects had been offered. BECO, through its three RFPs, has been responsible for nearly $60 \%$ of the state's capacity acquired through bidding.

Several utilities that conducted early solicitations have experienced high attrition rates for winning projects. This has occurred primarily because of siting difficulties. This experience has led utilities to more highly value site control and permitting status in project evaluation. The slowdown in regional load growth also has created a situation in which several larger projects already under development are undersubscribed. Thus, many developers are bidding the nonsubscribed pieces of these projects in current RFPs. These projects are clearly advantaged because of their advanced development stage.

${ }^{5}$ E. Kahn, et al., Evaluation Methods in Competitive Bidding for Electric Power, Lawrence Berkeley Laboratory, LBL-26924, June 1989. 


\section{MA - Bidding Winners by Fuel Type}

\section{(1195.7 MW)}

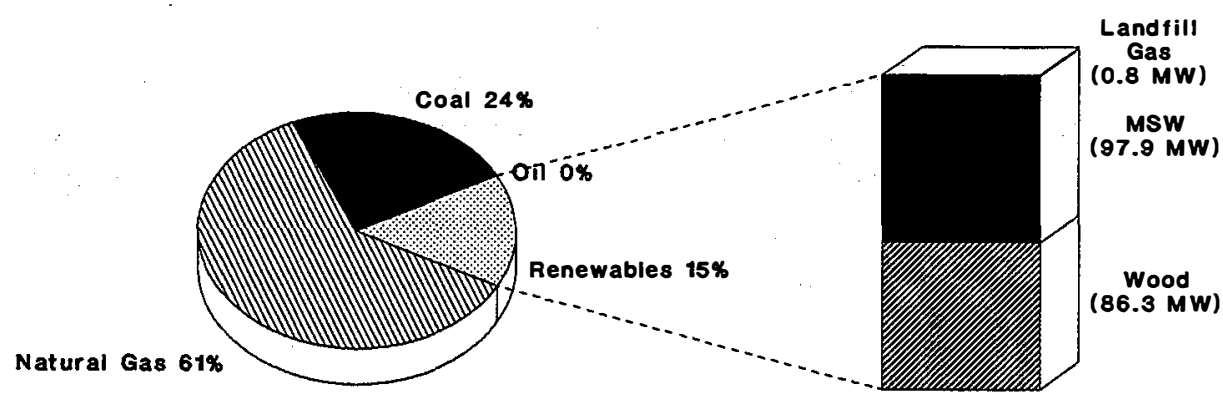

One would expect that the smaller size of some of the utility procurements would benefit renewables projects since these projects also tend to be smaller in size. Other than BECO, all of the state's bidding solicitations have been for less than $90 \mathrm{MW}$. Looking at these smaller solicitations, renewables represent $32 \%$ of winning capacity versus less than $5 \%$ in the three BECO solicitations, which have ranged from 132 to $200 \mathrm{MW}$. However, the increased marketing of nonrenewable project entitlements, as noted above, may impact this trend in the future.

BECO and Eastern Edison, with their third RFPs, were the first Massachusetts utilities to solicit capacity since the DPU required the incorporation of monetary values for environmental externalities into the bidding process. Based on the air emissions values set by the DPU, the weighted externality cost of the BECO avoided unit (a 306-MW natural-gas-fired combined cycle unit with a 1994 in-service date) is $1.33 \notin / \mathrm{kWh}$ while the weighted average externality cost of the marginal (existing) BECO unit prior to 1994 is $3.19 \notin / \mathrm{kWh}$ (both in 1989 dollars). The BECO RFP is self-scoring, has a 20-year price evaluation, and is open to only QFs and IPPs. The Eastern RFP was limited to QFs. Both utilities selected pieces of gas cogeneration projects as the winning bids. These selections mirror the bidding results in New York, where the inclusion of environmental externality values has largely benefited gas-based projects. 


\section{Nevada}

\section{Regulatory Actions}

No formal bidding rules have been adopted. However, the Public Service Commission (PSC) has allowed the regulated utilities to conduct bidding as a mechanism for receiving capacity offers for contract negotiation.

In January 1991, the PSC established a rule for the consideration of economic and environmental externalities in utility resource planning. The rulemaking was in response to a state legislative mandate stating that appropriate preference may be given to those resources that "provide the greatest economic and environmental benefits to the state." ${ }^{\text {" }}$ It is anticipated that the state's utilities will include these considerations in future bidding solicitations.

\section{Bidding Status}

Sierra Pacific Power Company is the only utility to have conducted bidding.

\begin{tabular}{||l|c|c|c|c||}
\hline \hline Utility & Year & $\begin{array}{c}\text { Requested } \\
\text { (MW) }\end{array}$ & $\begin{array}{c}\text { Total Selected } \\
\text { (MW) }\end{array}$ & $\begin{array}{c}\text { RE Selected } \\
\text { (MW) }\end{array}$ \\
\hline \hline Sierra Pacific \#1 & 1988 & 125 & 163 & $13(8 \%)$ \\
\hline Sierra Pacific \#2 & 1989 & 197 & 107.4 & $82.4(77 \%)$ \\
\hline
\end{tabular}

\section{Impact on Renewables}

The first Sierra Pacific solicitation (1988) was for $125 \mathrm{MW}$ of long-term capacity to be supplied starting from 1989-1992. All supply sources, non-utility and utility, were allowed to participate. Of the total of $3200 \mathrm{MW}$ of proposals received, $45 \%$ was renewables based, including $1055 \mathrm{MW}$ of geothermal, and more than $40 \%$ was existing capacity offered by utilities. A multistage procedure was used to evaluate the proposals. The first stage was a screening of the levelized project costs over a range of possible capacity factors. The lowest cost options were then evaluated in a production costing model to estimate potential impacts on revenue requirements against a predetermined reference case. Project options were then grouped in an attempt to capture beneficial influences that several different projects together might bring to the system. A number of nonprice factors were considered qualitatively in this process, including financial viability, transmission impacts, dispatchability, and operational risks.

\footnotetext{
${ }^{6}$ Public Service Commission of Nevada, In Re Rulemaking Regarding Resource Planning Changes Pursuant to SB 497, Docket No. 89-752, February 1, 1991.
} 


\section{NV - Bidding Winners by Fuel Type}

(270.4 MW)

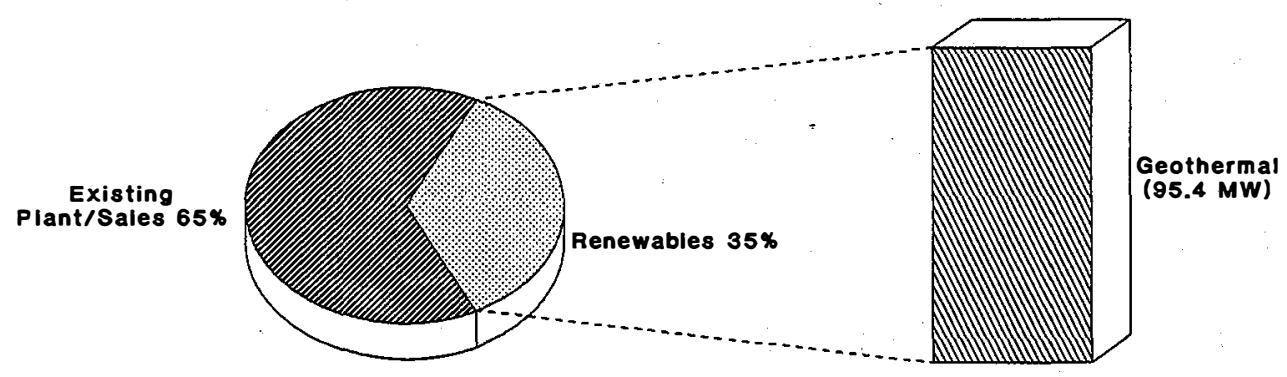

Sierra Pacific ultimately negotiated power contracts with two Northwest utilities (10-year and 20year contracts) to provide $150 \mathrm{MW}$ from existing supplies as the lowest cost and highest value options. A 30-year contract for a 13-MW expansion of an existing non-utility-developed geothermal project was also negotiated as insurance to meet a regulatory mandate for $85 \mathrm{MW}$ of qualifying facility (QF) capacity by the end of 1990 . Both price and the utility's short time frame played an important role in the selection. The first year cost under both utility contracts is less than $3.0 \phi / \mathrm{kWh}$, while the first year cost for the geothermal project is about $5.3 \phi / \mathrm{kWh}$.

A second solicitation was held by Sierra Pacific in 1989 for a total of 197 MW of long-term capacity (10-30 years) over the 1991-1997 time frame. Although the utility's preferred plan called for combustion turbines, all load types were encouraged. Many of the same price and nonprice factors were used in the evaluation of proposals and additionally, economic and environmental benefits were included for projects ranked closely. As in the first RFP, no specific information was provided on the weighting or scoring of the evaluation criteria.

Again, Sierra Pacific received a large response: 39 proposals for 2600 MW. Sierra selected 82.4 MW of geothermal projects for contract negotiation, along with a 25-MW utility purchase option. (The lower than requested capacity total was due to a downward revision in capacity needs.) The most important factor in this result was the more limited transmission capability to import power from other utilities given the $150 \mathrm{MW}$ of imports procured with the first RFP. Also, the price differentials between utility sales proposals and the geothermal projects had narrowed significantly since the first RFP. The geothermal projects also were able to accept lower capacity payments in the later years of the contracts. Economic and environmental considerations did not play an important role in the selections. 


\section{New Hampshire}

\section{Regulatory Actions}

No formal bidding rules have been adopted. In a 1988 decision, the Public Utilities Commission (PUC) required the state's regulated utilities to file an integrated least cost resource plan every two years. Utilities must file a qualifying facility $(\mathrm{QF})$ power purchase negotiation plan if a capacity need is identified in the first eight years of the forecast period. The PUC Order stresses increased use of private negotiations for QF contracting over the standard offer contracting of the past. Utilities may use competitive bidding as a mechanism for conducting these negotiations. Negotiable terms may include, among other things, "price, front end loading, security arrangements, dispatchability, and timing of the QF capacity addition." The PUC reviews any resulting contracts in cost recovery hearings. ${ }^{?}$

In the New Hampshire Limited Electrical Energy Producers Act (LEEPA), a preference was expressed for small renewable energy-based projects that provide fuel diversity and decrease the state's dependence on fossil fuels. Accordingly, standard long term levelized rates had been offered to QFs as a development inducement. However, in its Order, the PUC stated that these rates are no longer required given the maturation of the $\mathrm{QF}$ industry.

\section{Bidding Status}

Two of the state's five regulated utilities have held solicitations.

\begin{tabular}{||l|c|c|c|c||}
\hline \hline Utility & Year & $\begin{array}{c}\text { Requested } \\
(\mathbf{M W})\end{array}$ & $\begin{array}{c}\text { Total Selected } \\
(\mathbf{M W})\end{array}$ & $\begin{array}{c}\text { RE Selected } \\
(\mathbf{M W})\end{array}$ \\
\hline \hline PSNH & 1989 & 50 & Rejected & -- \\
\hline UNITIL & 1991 & 75 & 85 & 0 \\
\hline
\end{tabular}

\section{Impact on Renewables}

In 1989, Public Service Company of New Hampshire (PSNH) conducted an all-source solicitation for $50 \mathrm{MW}$ of intermediate and peaking power. PSNH emphasized feasibility first, under a strict set of criteria, and price second. Although PSNH created a 20\% set-aside for renewables, based on the state's renewables preference, front-loading of price was discouraged by a price evaluation that focused on the payment stream over the first five years. The utility evaluated 14 bids for a total $470 \mathrm{MW}$, all of which passed the utility's initial feasibility test, but the utility rejected all of the proposals as not meeting its avoided cost projections.

\footnotetext{
${ }^{7}$ Public Utilities Commission of New Hampshire, Order No. 19,052, April 7, 1988
}

$$
\text { A }-24
$$




\section{NH - Bidding Winners by Fuel Type}

(85 MW)

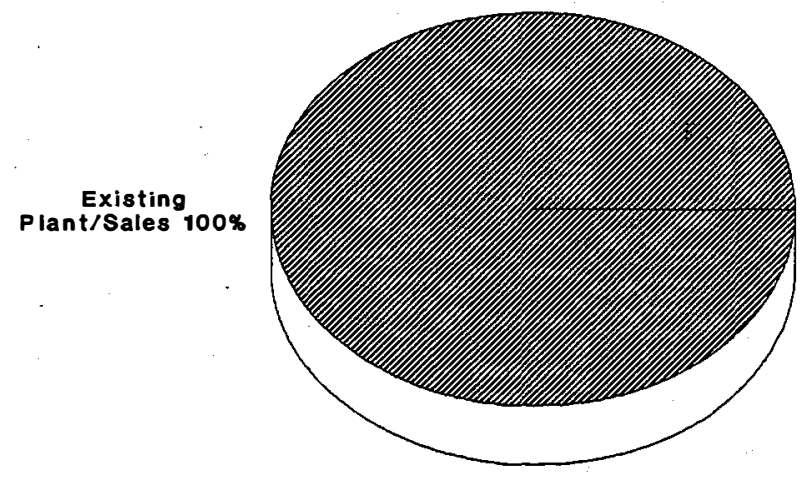

UNITIL Power Corp. (UPC), a subsidiary of UNITIL Corporation, which supplies wholesale power and transmission services to two UNITL retail distribution companies (Concord Electric Company and Exeter \& Hampton Electric Company), issued an RFP in 1991 for 75 MW of resources in small blocks from 1993-1996. Peaking and intermediate resources were preferred in the near term and base load after 1996.

UPC received 80 proposals for more than $3000 \mathrm{MW}$ of capacity. The expressed goal of the evaluation process was "to achieve a highly cost effective and robust system delivering average system costs under the general rate of inflation and providing a reasonable balance of resources avoiding dependence on any one unit, fuel, technology, transmission path, vendor, or contract." Given the surplus capacity situation in New England, UPC received many proposals from both utilities and non-utility generators for capacity entitlements to existing or nearly completed plants. UPC noted that "Facilities at the very early stage of development and unsubscribed projects that were significantly larger than UPC's needs, as well as high priced proposals, were not actively pursued because of the risk that these projects would not reach maturity in a surplus market." Given this situation, the final contract award group included seven proposals for $85 \mathrm{MW}$ from existing utility-related plants, including $20 \mathrm{MW}$ from the Ocean States Power project. 


\section{New Jersey}

\section{Regulatory Actions}

Pursuant to a 1988 Stipulation of Settlement between the Board of Regulatory Commissioners (BRC, formerly the Board of Public Utilities) and other state agencies, the state's electric utilities, and non-utility power generators, competitive bidding has been adopted as the mechanism for the procurement of capacity from alternative power producers (APPs), as well as for large-scale conservation projects, to satisfy portions of the utilities' future capacity and energy needs. ${ }^{8}$ Bidding is to be conducted by the individual utilities on an annual basis, beginning in 1989, as resource needs dictate. However, the utilities retain the right to build their own capacity as long as this option is consistent with the state's least cost planning principles.

Under the terms of the five-year agreement, the state's utilities are guaranteed full cost recovery on APP power procured through the bidding process. The utilities develop their own bidding process, subject to general guidelines and BRC approval, but must provide sufficient information to bidders on selection criteria and weighting to allow self-scoring. Utilities may include independent power producers (IPPs) in their solicitations, however qualifying facilities (QFs) are to be given preferential weighting. Host utility affiliates were precluded from participating during the first three years of the process, after which time affiliates are eligible to bid. (This prohibition was subsequently extended to September 1992.) In the stipulation, the state's utilities agreed to limited wheeling, with compensation, for bidding winners as long as sufficient transmission capacity exists.

The utilities' avoided cost, projected over 25 years, serves as the price ceiling in the bidding process. Bid prices may be front-loaded. The settlement agreement stipulated that economic factors, which are limited to considerations of price, dispatchability, and security provisions for front-loaded payments, be given a maximum weight of 55\%; project status and viability factors be given a minimum weight of $25 \%$; and non-economic factors, to "be implemented in a manner which provides that the development of PURPA qualifying cogeneration and small power production facilities will be promoted," be given a minimum weight of $20 \%$. Evaluation criteria for non-economic factors must include fuel type, location, environmental benefits, and fuel efficiency.

Projects must demonstrate a minimum level of development to become eligible to participate in the bidding process. The BRC also has authorized strict liquidated damages provisions, tied to the achievement of major project development milestones, to further discourage nonviable projects. QFs up to $10 \mathrm{MW}$ in size are exempt from the bidding process; contracts for these projects are negotiated on the basis of avoided costs. Utilities must also provide standard offer contracts, at full avoided cost, to qualifying resource recovery facilities located within their

\footnotetext{
${ }^{8}$ State of New Jersey, Board of Public Utilities, In the Matter of Consideration and Determination of Cogeneration and Small Power Production Standards Pursuant to the Public Utility Regulatory Policies Act of 1978, Docket No. 8010687B, Stipulation of Settlement, July 1, 1988.
} 
service territory for three years, after which time these facilities will be required to participate in future bidding solicitations. Standard offer contracts are also available to QFs of any size outside of the bidding process, however, payments are based primarily on avoided energy costs.

\section{Bidding Status}

Three of the state's four utilities have conducted bidding. (The status of the Rockland Electric bidding program is summarized under Orange and Rockland in New York.)

\begin{tabular}{||l|c|c|c|c||}
\hline \hline Utility & Year & $\begin{array}{c}\text { Requested } \\
\text { (MW) }\end{array}$ & $\begin{array}{c}\text { Total Selected } \\
\text { (MW) }\end{array}$ & $\begin{array}{c}\text { RE Selected } \\
\text { (MW) }\end{array}$ \\
\hline \hline JCP\&L & 1989 & $270^{*}$ & 242.7 & $17.7(7 \%)$ \\
\hline \hline PSE\&G & 1989 & 200 & 263.3 & $129.3(49 \%)$ \\
\hline
\end{tabular}

"Excluding $30 \mathrm{MW}$ in standard offers for plants less than $10 \mathrm{MW}$

\section{Impact on Renewables}

Only one round of bidding has been held in New Jersey. Both Jersey Central Power and Light (JCP\&L) and Public Service Electric and Gas (PSE\&G) issued joint supply and demand solicitations in 1989.

JCP\&L solicited proposals for $270 \mathrm{MW}$ of non-utility-owned capacity, including IPPs, to be online by mid-1994. Contracts would be for 10-20 years. JCP\&L followed the stipulated evaluation weighting of 55 points for price, 25 points for project status and financial viability and 20 points for non-economic factors. In addition, bonus points were awarded for dispatchability and the provision of liquid security. The JCP\&L RFP included self-scoring tables and a computer spreadsheet, providing "a self-explanatory 'cookbook' for determining project eligibility and project score." Eleven supply-side projects were bid, including coal (four); natural gas (two); wood (two - one dropped out after submission); municipal solid waste (MSW) (two); and culm (one). Out of the total of $768 \mathrm{MW}$ bid, JCP\&L selected two 100-MW coal projects, a 17.7 wood-based plant, and $25 \mathrm{MW}$ of demand-side management (DSM) projects. Price turned out to be an important factor in the selections. The two MSW projects (out of state) were disqualified for lacking fuel delivery contracts.

The PSE\&G solicitation also followed the stipulated weighting procedure of price (55\%), project status and viability (25\%), and noneconomic (20\%) factors. The RFP also was self-scoring. Although no restriction was placed on project location, the RFP noted that projects in certain locations would be evaluated more favorably. For projects located outside of the utility's service territory, developers are responsible for arranging transmission to PSE\&G. After receiving about $5000 \mathrm{MW}$ of proposals, PSE\&G selected two MSW projects totaling 107.3 MW, one woodwaste-fired project (22 MW), and an 81-MW coal project, as well as $53 \mathrm{MW}$ of DSM. 


\section{NJ - Bidding Winners by Fuel Type}

(506 MW)

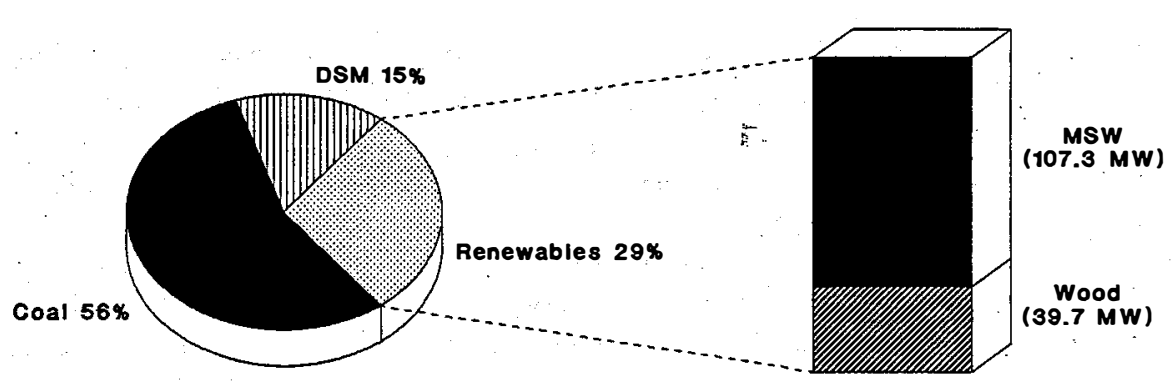

The New Jersey bidding process appears to provide one of the more favorable treatments for renewables of any state. First, QFs are to be given preferential treatment in the weighting of non-economic factors. Second, no penalty is assigned for front-loaded payment proposals. In fact, security provisions are only required if the amount of payment levelization proposed exceeds $35 \%$ of forecasted avoided cost (20\% for oil and gas projects). And QFs of $10 \mathrm{MW}$ or less are eligible for standard offer purchase contracts outside of the bidding process. Renewables (MSW and wood) represent almost $30 \%$ of the capacity selected under bidding in the state. However, coal projects represent more than half of the capacity selected. This result is contrary to that of New York, where a comparable consideration of environmental impacts has favored natural gas selection over coal. 


\section{New York}

\section{Regulatory Actions}

In an opinion issued in 1988, the Public Service Commission (PSC) directed each of the state's seven investor-owned electric utilities to develop competitive bidding programs for obtaining additional capacity. ${ }^{9}$ Bidding procedures and RFPs are subject to public review and PSC approval. While the utilities were given the flexibility to develop bidding programs to fit their particular needs, the PSC stated that the following variables should be included in each utility's ranking formula: overall price level; price schedule, with negative implications for levelized or front-loaded price schedules; price risk, with bid prices tied to potentially volatile fuel price indexes considered a negative; dispatchability, with the degree of dispatchability a positive; fuel diversity, with fuel sources consistent with optimizing the utility's overall fuel mix a positive factor; location, proximity to load centers and effect on transmission system; availability of production, with high availability during peak load periods a potential plus; environmental impacts; and likelihood of project completion, including consideration of developer experience, technology track record, and permitting needs.

The utility's avoided cost, adjusted for the above factors, sets a ceiling on bid prices. Losing bidders may receive contracts for avoided energy costs only. The PSC allows bidding programs to be all-source, including host utility subsidiaries, as long as adequate safeguards are taken to protect against self-dealing. Small power producers, $2 \mathrm{MW}$ or less in size, are allowed to bypass the auction process and receive standard contracts with payment equal to the average of the winning bids from the most recently completed auction.

As utility proposals were received and reviewed, the PSC refined its guidance on the bidding selection criteria. The PSC generally adopted a maximum weighting of about $15 \%$ for environmental factors, noting in one RFP review that "because projects that are environmentally inferior (although approvable) might benefit from higher scores on their price bids, a fair bidding process should allow projects to receive higher scores based on environmental superiority."10 Monetary values for environmental factors, developed by the PSC staff, are compared to the average winning bid price to derive a scoring weight.

The PSC also later recognized the bias implicit in favoring projects with rates tied to annualized avoided costs as opposed to levelized or front-loaded payment structures. In another RFP review, the PSC stated that "in order to encourage project sponsors to undertake the additional capital investment necessary to achieve more than the minimal compliance with environmental standards,

\footnotetext{
${ }^{9}$ State of New York, Public Service Commission, Opinion and Order Concerning Bidding, Avoided-Cost Pricing, and Wheeling Issues, Opinion No. 88-15, June 3, 1988.

${ }^{10}$ State of New York, Public Service Commission, Opinion and Order Establishing Guidelines for Bidding Program (re Orange and Rockland Utilities, Inc.), Opinion No. 89-7, April 13, 1989.
}

A -29 
the weight assigned to the environmental factor should be sufficient to vitiate the potential scoring advantage of low-capital-cost, minimally-complying projects."11

Finally, the PSC recognized that an economic development criteria variable should be included to value project benefits related to in-state business expansion or retention. However, being difficult to evaluate at the time, the PSC left the valuation of this factor to the individual utilities.

\section{Bidding Status}

Each of the seven IOUs have issued bidding RFPs.

\begin{tabular}{||l|c|c|c|c||}
\hline \hline Utility & Year & $\begin{array}{c}\text { Requested } \\
(\mathbf{M W})\end{array}$ & $\begin{array}{c}\text { Total Selected } \\
(\mathbf{M W})\end{array}$ & $\begin{array}{c}\text { RE Selected } \\
(\mathbf{M W})\end{array}$ \\
\hline \hline Orange \& Rockland & 1989 & 200 & 198.5 & 0 \\
\hline Con. Edison & 1990 & 200 & 214.2 & $17.7(8 \%)$ \\
\hline LILCO & 1990 & $150^{*}$ & 150 & 0 \\
\hline NIMO & 1990 & 350 & 405 & 0 \\
\hline Central Hudson \#1 & 1991 & $50^{*}$ & Rejected & --- \\
\hline Central Hudson \#2 & 1991 & 300 & Rejected & --- \\
\hline NYSEG & 1991 & $100^{*}$ & Rejected & --- \\
\hline Rochester & 1991 & 70 & Rejected & --- \\
\hline \hline
\end{tabular}

"Supply-side portion only

\section{Impact on Renewables}

Since each utility was allowed to develop its own weighting procedures, the actual weighting of selection factors differed among the various RFPs. Price factors, including rate and structure, accounted for between $50 \%$ and $70 \%$ of the total weighting, and price was generally evaluated over only a 15-year period. Avoided cost proxies ranged from a natural gas combined cycle plant to plant life extension and power purchase contracts. Three of the seven utilities sought peaking capacity only.

Four of the seven utilities selected winners, while the three utilities seeking peaking capacity rejected all bids. Out of nearly $1000 \mathrm{MW}$ of winners, only one renewables project, a 17.7-MW waste-wood-fired project, was selected.

\footnotetext{
${ }^{11}$ State of New York, Public Service Commission, Opinion and Order Establishing Guidelines for Bidding Program (re Long Island Lighting Company), Opinion No. 89-18, June 13, 1989.
}

$$
\text { A - } 30
$$




\section{NY - Bidding Winners by Fuel Type}

\section{(968 MW)}

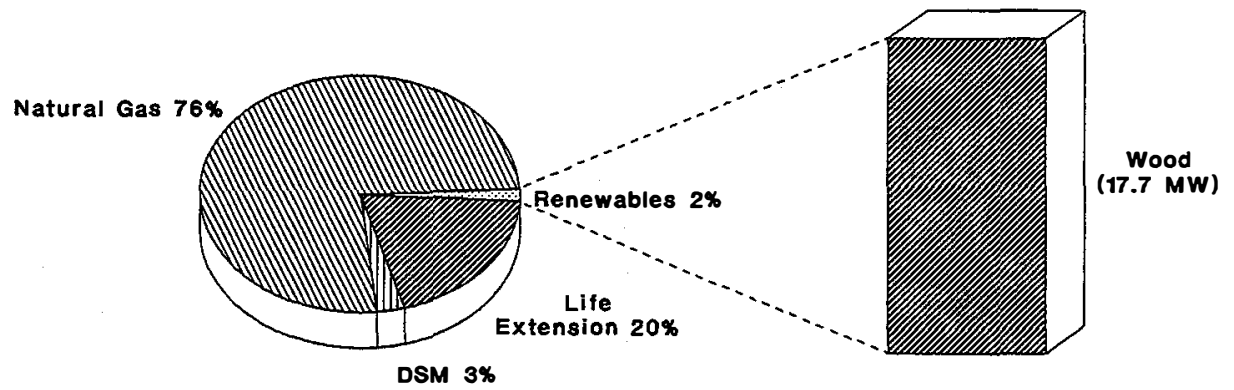

Given the results of the first round of utility bidding, the state has expressed particular concern over the lack of success of renewables-based projects. In the July 1991 draft of the New York State Energy Plan, the following was written:

Although the scoring systems vary from company to company, generally these (renewable) technologies would not be expected to score well on the scoring of overall price, price pattem (i.e., they require high payments in the early years), and operational characteristics such as dispatchability. On the other hand, these technologies were expected to do fairly well on scoring factors having to do with environmental effects, price stability (i.e., firm bid prices rather than indexed prices), and fuel diversity; these latter two factors, however, were not heavily weighted in most utilities' scoring systems. In sum, the weight given to those variables on which renewable and waste-to-energy facilities score well was not high enough to overcome the disadvantage of the scoring factors on which gas-fired facilities score better than these technologies.

As a result of the perceived inability to provide a level playing field for renewables in bidding, the final New York State Energy Plan recommends the following:

The PSC should take actions necessary to require electric utilities in New York to develop a market test/demonstration program to procure $300 \mathrm{MW}$ of a diverse range of renewable resources by January 1, 1994 (on-line by 1998). Such actions should provide guidance to utilities with respect to: altemative methods of procuring capacity; differential treatment for emerging technologies/innovative applications (e.g., solar, wind and hybrid) as compared to mature technologies; individual utility and/or poolwide responsibilities to obtain capacity; requirements related to obtaining a diverse set of technologies; and establishment of an acceptable price premium, above utility avoided costs, which utilities should be expected to pay to procure this capacity. 


\section{North Carolina}

\section{Regulatory Actions}

No formal bidding rules have been adopted. However, regulated utilities are allowed to solicit capacity through bidding.

\section{Bidding Status}

One municipal power agency has conducted a bidding solicitation.

\begin{tabular}{||l|c|c|c|c||}
\hline \hline Utility & Year & $\begin{array}{c}\text { Requested } \\
(\mathbf{M W})\end{array}$ & $\begin{array}{c}\text { Total Selected } \\
(\mathbf{M W})\end{array}$ & $\begin{array}{c}\text { RE Selected } \\
(\mathbf{M W})\end{array}$ \\
\hline \hline NCEMPA & 1990 & 240 & Rejected & -- \\
\hline
\end{tabular}

\section{Impact on Renewables}

The North Carolina Eastern Municipal Power Agency (NCEMPA) supplies power to 23 municipalities that are connected to the transmission system of the Carolina Power \& Light Company (CP\&L) and 9 municipalities that are connected to the transmission system of the Virginia Power Company. In 1990, NCEMPA solicited proposals for up to 240 MW of peaking capacity for the 1994-1998 time frame "to reduce its future purchases of capacity and energy from CP\&L," primarily nuclear entitlements. The solicitation sought to compare proposals from both utility and non-utility entities against NCEMPA's own combustion turbine build option.

The NCEMPA evaluation involved an initial economic screening based on levelized total cost over three time periods: the first five years, the first 10 years, and the total contract term. While price was deemed most important, a number of nonprice factors were also considered, including

- project viability, including commercial experience with the technology and the probability of obtaining permits

- level of project development at the time of the bid evaluation

- $\quad$ experience of the Bidder in developing, owning, and operating similar facilities

- financial strength of the Bidder and

- $\quad$ security of fuel supply and wheeling arrangements, if applicable.

In response to the RFP, NCEMPA received five bids representing a total of $454 \mathrm{MW}$. The proposed projects, ranging in size from $38 \mathrm{MW}$ to $120 \mathrm{MW}$, were based on either natural gas or petroleum fuel combustion. NCEMPA ultimately rejected all the proposals in favor of its own construction of three 80-MW gas-fired combustion turbine units. 


\section{Ohio}

\section{Regulatory Actions}

In 1991, the Public Utilities Commission (PUC) issued a policy statement endorsing competitive bidding and initiated a rulemaking to establish a system of competitive bidding. ${ }^{12}$ At the time, the PUC staff recommended that the host utility be a part of the bidding process, with commensurate regulatory oversight, and that the bidding policy "provide open access to the intrastate transmission grid for winning bidders, for the amount of capacity offered by the winning bidders in a host utility's bid solicitation." PUC involvement in the bidding process would be limited to the development of the overall bidding framework and review of utility RFPs. In late 1992, the PUC issued its proposed rules for comment.

\section{Bidding Status}

One municipal power agency, not under PUC jurisdiction, has conducted bidding.

\begin{tabular}{||l|c|c|c|c||}
\hline \hline Utility & Year & $\begin{array}{c}\text { Requested } \\
\text { (MW) }\end{array}$ & $\begin{array}{c}\text { Total Selected } \\
\text { (MW) }\end{array}$ & $\begin{array}{c}\text { RE Selected } \\
(\mathbf{M W})\end{array}$ \\
\hline \hline AMP-Ohio & 1989 & 300 & 275 & 0 \\
\hline \hline
\end{tabular}

\section{Impact on Renewables}

American Municipal Power-Ohio (AMP-Ohio), a wholesale power supplier to 76 of the state's municipal utilities, conducted a bidding solicitation in 1989 to secure low-cost future power supplies for its members because of the availability of surplus power in the Midwest. Although selection terms were not disclosed, it has been reported that price and reliability were the most important decision factors. AMP-Ohio wanted projects to have adequate backup generation capabilities, which worked against the selection of non-utility generators. AMP-Ohio selected $275 \mathrm{MW}$ in plant and system sales from three utilities.

\footnotetext{
${ }^{12}$ Public Utilities Commission of Ohio, In the Matter of the Commission's Investigation into Competitive Bidding for the Acquisition of New Electricity Capacity, Finding and Order, Case No. 90-725-EL-COI, March 28, 1991.
}

A - 33 


\section{$\mathrm{OH}$ - Bidding Winners by Fuel Type}

(275 MW)

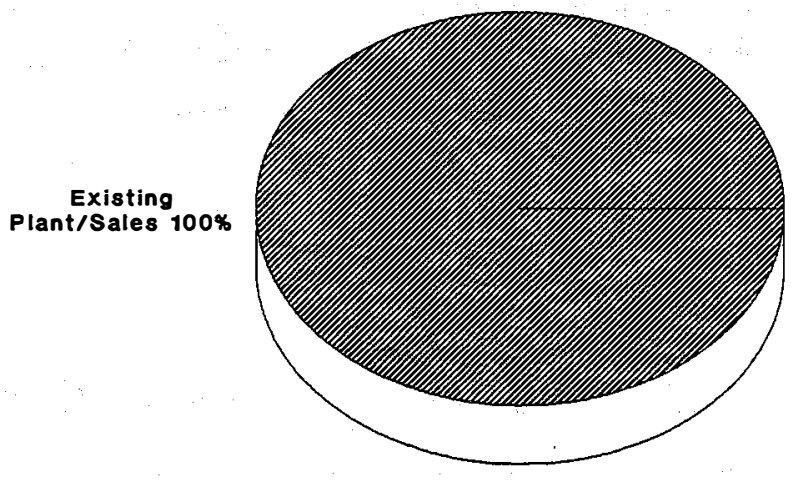

A -34 


\section{South Carolina}

\section{Regulatory Actions}

No formal bidding rules have been adopted. Plans for procuring capacity are included in a utility's integrated resource plan (IRP) filing and are reviewed on an ad hoc basis by the Public Service Commission (PSC).

\section{Bidding Status}

One public power authority has conducted bidding.

\begin{tabular}{||l|c|c|c|c|}
\hline Utility & Year & $\begin{array}{c}\text { Requested } \\
\text { (MW) }\end{array}$ & $\begin{array}{c}\text { Total Selected } \\
\text { (MW) }\end{array}$ & $\begin{array}{c}\text { RE Selected } \\
\text { (MW) }\end{array}$ \\
\hline \hline Santee Cooper & 1990 & 300 & 300 & 0 \\
\hline
\end{tabular}

\section{Impact on Renewables}

The South Carolina Public Service Authority, also known as "Santee Cooper," released an RFP at the end of 1990 for up to $300 \mathrm{MW}$ of short-term power resources for the 1992-1995 time frame. Santee Cooper, which is interconnected with several investor-owned utility systems, both provides retail service and sells wholesale power to one cooperative association and two municipalities. The capacity requested will be utilized to meet an interim period of need until longer term resources, already under development, become available in 1995. The goal of the solicitation was "to determine whether power is available for purchase that would meet the Authority's objectives at a lower cost to the Authority and its customers, or would provide other advantages, when compared to the Authority constructing its own new peaking capacity." A companion solicitation sought proposals to purchase excess capacity from Santee Cooper in 1995 and 1996.

The proposal evaluation criteria weighed capacity pricing most heavily but also considered nonprice factors such as reliability, scheduling and dispatching flexibility, status of facilities, and contractual relationship. Respondents were also urged to note other factors that might provide value vis-a-vis other proposals. In response to the RFP, Santee Cooper received seven proposals, five from utilities and two from independent power producers (IPPs). The winning proposal was for up to $300 \mathrm{MW}$ of capacity and energy from Virginia Power to be wheeled by Carolina Power $\&$ Light. No responses were received from the second solicitation. 


\section{SC - Bidding Winners by Fuel Type \\ (300 MW)}

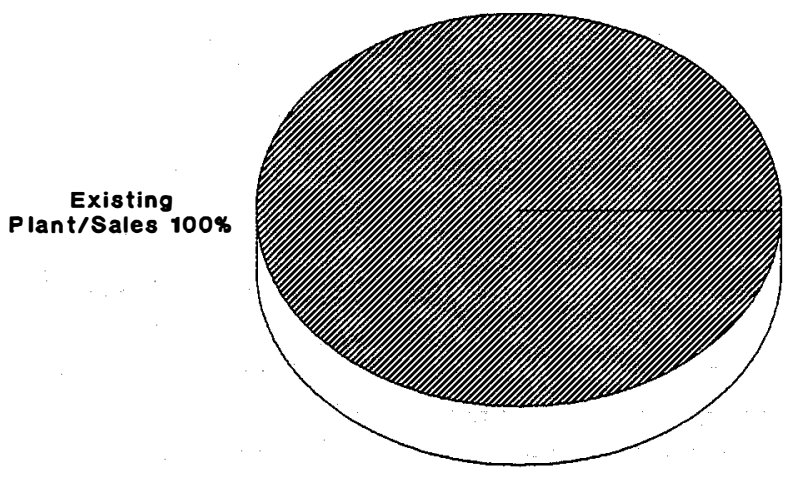

A -36 


\section{Texas}

\section{Regulatory Actions}

In 1992, the Public Utility Commission (PUC) adopted an interim rule on competitive bidding requiring that any utility filing a notice of intent (NOI) to build new capacity solicit capacity from external sources to compare against its build option. In the past, regulated utilities, which include public utilities, had been allowed to solicit capacity from qualifying facilities (QFs) and negotiate contracts through bidding with PUC approval.

\section{Bidding Status}

Only public utilities have conducted bidding. ${ }^{13}$

\begin{tabular}{|c|c|c|c|c|}
\hline Utility & Year & $\begin{array}{c}\text { Requested } \\
\text { (MW) }\end{array}$ & $\begin{array}{c}\text { Total Selected } \\
(\mathbf{M W})\end{array}$ & $\begin{array}{c}\text { RE Selected } \\
\text { (MW) }\end{array}$ \\
\hline Sam Rayburn Coop & 1988 & $25-40+^{*}$ & Rejected & -- \\
\hline Brazos Elec Coop & 1990 & 208 & Rejected & --- \\
\hline NE Texas Elec Coop & 1990 & $25-75$ & 30 & 0 \\
\hline City of Weatherford & 1990 & $24-45$ & Pending & -- \\
\hline East Texas Elec Coop & 1991 & 100 & Pending & -- \\
\hline Rio Grande Elec Coop & 1991 & 12 & Pending & -- \\
\hline Tex-La Electric Coop & 1992 & $115-185$ & Pending & -- \\
\hline
\end{tabular}

*Sought blocks of capacity in this range.

\section{Impact on Renewables}

Three of the six utilities that have conducted solicitations have announced results. The Sam Rayburn G\&T Electric Cooperative, Inc. (SRG\&T), serving three member distribution cooperatives, released an RFP in 1988 seeking intermediate and peaking resources beginning in 1989 to "provide economical and reliable electricity over a sufficiently long term." SRG\&T was in the process of negotiating a 60-MW capacity purchase from an existing utility coal-fired plant and used this unit as their benchmark. The primary evaluation considerations were: "(1) the cost

\footnotetext{
${ }^{13}$ The one exception is Texas Utilities Electric, which in 1991 issued an "information request" for capacity proposals to compare against its own build options.
} 


\section{TX - Bidding Winners by Fuel Type}

(30 MW)

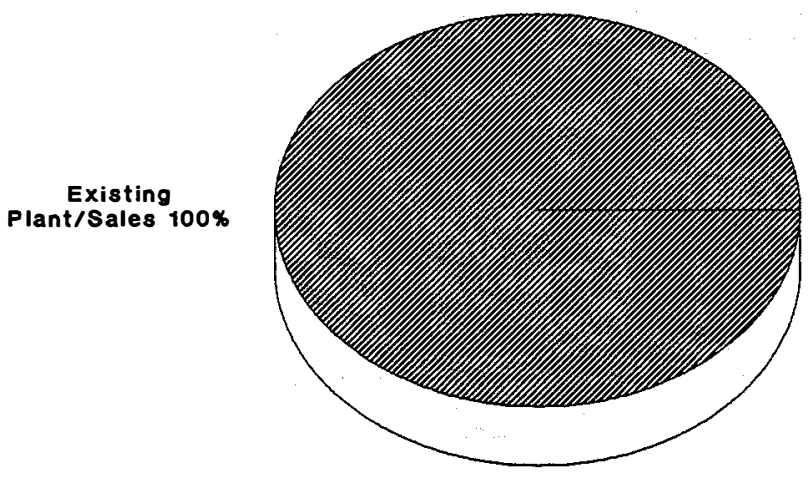

of electricity offered and (2) the respondent's proven ability to meet SRG\&T's specific electricity requirements." Guaranteed prices were preferred and dispatchability was emphasized. The solicitation was open to both utility and non-utility entities. Three proposals were received: two for gas-fired cogeneration units (47 MW and $63 \mathrm{MW}$ ) and one for a 25- to 40-MW sale from a municipal utility. All three proposals were rejected as more costly than the benchmark utility sale.

In 1990, Brazos Electric Cooperative, serving 20 member distribution cooperatives, solicited proposals for $208 \mathrm{MW}$ of peaking capacity. The main selection criteria were cost at or below the utility's avoided cost; the location of the proposed unit and the reliability of transmission; fuel source and reliability; and the financial strength of the proposer. In response to the RFP, Brazos received four proposals: a 16-MW gas cogeneration project; a 208-MW gas-fired independent power producer (IPP) project; and two utility proposals for a 208-MW sale. All of the bids were rejected as being more costly than the utility's build option. Brazos is currently negotiating with the PUC for construction of a 208-MW gas-fired peaking unit.

Also in 1990, Northeast Texas Electric Cooperative, Inc. (NTEC), serving six distribution members, solicited proposals for long-term capacity blocks of between $25 \mathrm{MW}$ and $75 \mathrm{MW}$. Evaluation criteria included price (economic feasibility), including considerations of front-end loading avoidance, fixed capacity charges, and fuel price stability; proposal viability; dispatchability; and deliverability. From the 10 responses received, NTEC selected $30 \mathrm{MW}$ of capacity from an existing utility-operated, coal-fired plant. 
The results of the other four solicitations have not been announced. The bidding results achieved thus far in Texas point out the market attractiveness to public utility entities of excess capacity from pre-existing, utility-owned units, particularly when interconnections exist with these utilities. 


\section{Vermont}

\section{Regulatory Actions}

No formal bidding rules have been adopted. The Public Service Board (PSB) failed to take formal action on a rulemaking docket filed in 1987 to consider competitive bidding. However, the PSB is once again investigating the establishment of a competitive procurement process because of its recent rejection of utility power purchase contracts with Hydro Quebec. Two of the state's investor-owned utilities (IOUs) held bidding solicitations in 1988 without formal PSB approval.

In 1983, the PSB adopted Rule No. 4.100 which set out the state procedure for power purchases from qualifying facilities (QFs). The Vermont Power Exchange, Inc. (VPX) was created to carry out.QF purchases and allocate the power on the basis of the utility's relative share of annual state electricity sales. All resulting utility power purchase contracts must be approved by the PSB.

In 1992, the PSB issued a draft proposal to establish bidding as the preferred mechanism for future resource procurements. If the proposal is formally adopted, the VPX would be eliminated as the vehicle for QF power purchases. The draft rule would also establish a class of "preferred" QFs based on environmental considerations. The preferred QFs would be eligible for long-term, levelized price contracts as well as wheeling rights. Preferred resources would include all renewables-based generators except for municipal waste incinerators.

\section{Bidding Status}

Two IOUs have conducted bidding. In addition, the Vermont Department of Public Service, a state agency representing ratepayers, has solicited capacity proposals.

\begin{tabular}{||l|c|c|c|c||}
\hline \hline Utility & Year & $\begin{array}{c}\text { Requested } \\
\text { (MW) }\end{array}$ & $\begin{array}{c}\text { Total Selected } \\
\text { (MW) }\end{array}$ & $\begin{array}{c}\text { RE Selected } \\
\text { (MW) }\end{array}$ \\
\hline \hline GMP & 1988 & $115-240$ & 60 & 0 \\
\hline CVPS & 1988 & 50 & 52.9 & $0.9(2 \%)$ \\
\hline VT DPS & 1989 & No Cap & On Hold & $-\cdots$ \\
\hline
\end{tabular}

\section{Impact on Renewables}

Green Mountain Power (GMP) was the first utility to solicit capacity in May 1988. Proposals were solicited from all sources to compare with existing utility purchase options for three capac- 


\section{VT - Bidding Winners by Fuel Type}

(112.9 MW)

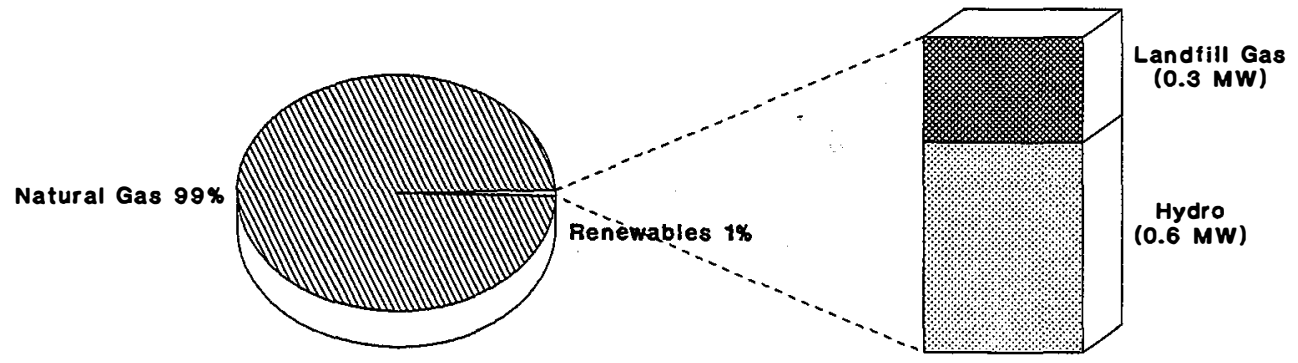

ity blocks: 20-65 MW for 1991-1997; 25-75 MW for 1992-2012; and 70-100 MW for 1995-2015. Price was the main evaluation factor, defined as the lowest present worth of power supply costs over a 30-year planning period. GMP also noted that a number of other factors would be considered, "such as technical feasibility, contingencies, permitting risks, security provisions, fuel diversity, project sponsor experience, and special interconnection and/or transmission system costs," but no explicit factor scoring was given. The GMP RFP stated that the utility would attempt to arrange transmission for successful bidders located outside of the GMP territory but that projects located within Vermont or able to interconnect directly to GMP would have an advantage because of reduced transmission charges. Out of about $800 \mathrm{MW}$ of proposals received, GMP selected a 60-MW natural-gas-fired cogeneration project. About one-fourth of the proposals received had been for renewables-based projects.

In October 1988, Central Vermont Public Service (CVPS) released an all-source RFP for 50 MW of capacity to be available starting in 1993. In direct contrast to the GMP RFP, the CVPS RFP offered a computer program to "assist (the proposer) in optimizing the bid ... to achieve the maximum value on CVPS's system." Projects were scored on the total expected value the project would bring to the CVPS system. The expected value was calculated as a function of its benefits (bid price versus "target price," dispatchability, location); liabilities (development failure, frontloading of prices); security (security provided to offset liabilities); and likelihood of successful operation (expressed as probability factors for successful development and successful operation). Although CVPS placed no restrictions on project location, transmission logistics were left to the project developer. From $658 \mathrm{MW}$ of proposals received, CVPS selected a 52-MW gas-fired cogeneration project and three small renewables-based projects totaling $0.9 \mathrm{MW}$. About $16 \%$ of the bids were renewables based. 
Finally, the Vermont Department of Public Service (DPS), a state agency representing ratepayers with wholesale power purchase authority, issued an all-source RFP in 1989 for 250 MW to compare against a power purchase option that the state's utilities had exercised for power from Hydro-Quebec. The DPS utilized the Central Maine Power RFP (see Maine), although the selection criteria were to be weighted differently. In response, the DPS received 21 proposals for about $1800 \mathrm{MW}$, mostly for gas- and coal-fired projects. Less than 6\% of the capacity offered was renewables based. None of the projects offered beat the price of the Hydro-Quebec contract. For this reason, and because the need for capacity has fallen, the selection of projects has been put on hold.

Since 1980, Vermont has secured $95 \%$ of its in-state generation additions (165 MW) from renewables, representing about $20 \%$ of the state's current peak power demand. In the past, renewables were eligible for long-term, levelized standard offer contracts. However, under bidding, renewables have not fared well. The preponderance of capacity selected has been natural gas based. 


\section{Virginia}

\section{Regulatory Actions}

In 1988, the State Corporation Commission (SCC) issued an order approving and legitimizing the concept of competitive bidding for use in the acquisition of new generating capacity pursuant to PURPA rules and regulations when surplus power is offered. ${ }^{14}$ This order was not a binding rule but rather provided general guidelines for conducting a utility bidding solicitation. The Order suggested that both price and nonprice factors should be considered in the selection process, including the "use of Virginia fuels, manpower and other State resources; the benefits to be derived by the industries and communities associated with particular projects; and other identifiable economic and societal benefits to the people of the Commonwealth."

The SCC envisioned an RFP process that would provide general information to developers on the evaluation process. The SCC also reserved the right to both review proposed RFPs, including selection criteria and weighting, and to provide a forum to arbitrate disputes. Finally, the SCC cautioned against making the selection criteria overly restrictive, such as requirements for full dispatchability of project output.

In a 1990 order, the SCC replaced these nonbinding guidelines with formal bidding rules to establish minimum requirements for bidding programs. ${ }^{15}$ In this ruling, the SCC broadened its earlier list of evaluation factors to include system fuel diversity, dispatchability, and environmental impact of projects, among other factors. However, the actual weighting of these factors is left to the utilities. Utilities are now given the option to solicit proposals from all potential sources, excluding direct utility affiliates, or to limit bidding to qualifying facilities (QFs). Utilities must also provide a benchmark price for the utility build option, either as part of the RFP or as submitted in confidence to the SCC. The order applies to both investor-owned and cooperative utilities operating in Virginia that choose to conduct bidding. Standard offer contracts remain available for QFs under $3 \mathrm{MW}$ in size.

\section{Bidding Status}

Virginia Power Company is the only one of five investor-owned utilities operating in the state to have conducted a bidding solicitation within Virginia and has singly contracted for more capacity through bidding than any other utility in the United States. One power agency also has solicited capacity.

\footnotetext{
${ }^{14}$ Commonwealth of Virginia, State Corporation Commission, Final Order, In the Matter of Adopting Commission Policy Regarding the Purchase of Electricity by Public Utilities from Qualifying Facilities When There is a Surplus of Power Available, Case No. PUE870080, January 29, 1988.

${ }^{15}$ Commonwealth of Virginia, State Corporation Commission, Final Order, In the Matter of Adopting Commission Rules for Electric Capacity Bidding Programs, Case No. PUE900029, November 28, 1990.
}

$$
\text { A }-43
$$




\begin{tabular}{||l|c|c|c|c||}
\hline \hline Utility & Year & $\begin{array}{c}\text { Requested } \\
\text { (MW) }\end{array}$ & $\begin{array}{c}\text { Total Selected } \\
(\mathbf{M W})\end{array}$ & $\begin{array}{c}\text { RE Selected } \\
\text { (MW) }\end{array}$ \\
\hline \hline Virginia Power \#1 & 1986 & 1000 & 1181 & $75(6 \%)$ \\
\hline Virginia Power \#2 & 1988 & 1750 & 2085.5 & $88.5(4 \%)$ \\
\hline Virginia Power \#3 & 1988 & 300 & Rejected & -- \\
\hline Virginia Power \#4 & 1989 & 1100 & 442 & $41(9 \%)$ \\
\hline Blue Ridge Power & 1991 & 100 & 180 & 0 \\
\hline
\end{tabular}

\section{Impact on Renewables}

The first of Virginia Power's solicitations (1986) predates the initial SCC bidding order. Concerned over an abundance of QF offers, the utility solicited sealed bids from potential developers, in a "selective procurement," as a capacity rationing mechanism. Since avoided cost payments had been previously determined, Virginia Power based its project selection on a number of nonprice factors; dispatch, timing, and location were the most prominent factors. The utility selected $1181 \mathrm{MW}$ out of $5000 \mathrm{MW}$ of responses to the 1000-MW solicitation. Almost $90 \%$ of the capacity selected was for gas-fired cogeneration projects. Two renewables-based projects were selected, a 15-MW biomass plant and a 60-MW municipal solid waste (MSW) plant, representing about $6 \%$ of the total capacity selected.

The second Virginia Power solicitation (March 1988) generated intense publicity both because of its size (1750 MW to be on-line by 1994) and its selection criteria. Seventy percent of the weighting was based on price factors and the remaining $30 \%$ on nonprice factors: viability of project (10\%); fuel and fuel diversity, including a preference for solid fuels and indigenous fuels (10\%); and other factors, including operational dispatch and project location (10\%). In addition, the price component emphasized full economic dispatch. Proposals were solicited from all sources. In addition, the utility offered to wheel power for losing bidders to another interconnected utility for a fee. Virginia Power ultimately selected $2086 \mathrm{MW}$ of capacity from 19 projects. Unlike the 1986 solicitation from which the overwhelming majority of capacity was gas based, over $50 \%$ of the capacity selected from this solicitation was coal based, which may be an indication of the importance given to the fuel category. Two projects selected were gasfired independent power projects (IPPs), representing 23\% of the total capacity solicited. Only $4 \%$ of the capacity selected was renewables based: a 76-MW wood waste project, a 10-MW MSW project, and a 2.5-MW hydro project.

Virginia Power's third solicitation (November 1988) was for 300 MW of "quick start" peaking capacity to be on-line within 12-18 months. Based on an evaluation of the 26 project proposals (totaling $2139 \mathrm{MW}$ ) received, the utility determined that the cost of all the proposals exceeded that of its own combustion turbine build option and the proposals were rejected. 


\section{VA - Bidding Winners by Fuel Type}

(3889 MW)

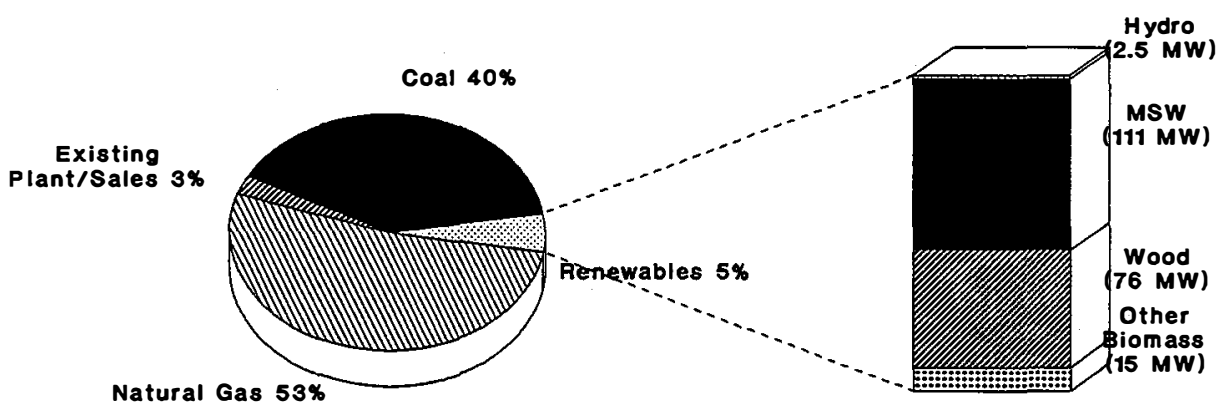

Finally, in 1989, Virginia Power conducted a fourth solicitation for 1100 MW of capacity from all sources for the 1995-1997 time frame. Again, a 70/30, price/nonprice factor weighting scheme was used. Out of the 78 proposals received (totaling 11,600 MW), the utility selected only three projects totaling $442 \mathrm{MW}$. Of these selections, two projects were coal based (401 MW total) and one project, $41 \mathrm{MW}$, was a waste-to-energy plant. Virginia Power stated that no other projects were selected because their costs were higher than the utility's build option. As a result, the utility announced plans to build its own 400-MW base load coal plant. The results of this solicitation again appeared to indicate a preference by Virginia Power for coal-based generation.

In 1991, Blue Ridge Power Agency, a two-year-old electricity wholesaler for several cities and cooperatives, which is not under SCC jurisdiction, solicited proposals for $100 \mathrm{MW}$ of peaking capacity for the 1993-1995 time frame to compare against wholesale power purchases. Blue Ridge ultimately selected $100 \mathrm{MW}$ of existing utility capacity and an 80-MW gas-fired combustion turbine project for final negotiations.

Clearly, renewables have not fared particularly well in Virginia's "competitive bidding laboratory," either in QF-only (RFP \#1) or all-source solicitations (RFP \#2 and \#4). Overall, renewables have accounted for less than $6 \%$ of the total capacity acquired by Virginia Power under bidding. Two potential contributory factors can be noted: (1) the low cost of fossil fuel alternatives and (2) an emphasis on solid and indigenous fuels, which while benefiting wood and MSW projects has greatly benefited coal as well. Although the SCC has ruled that utilities must consider environmental factors in all future solicitations, these factors have not yet been articulated or tested. Presumably, renewables would score higher in this respect. The results of the Blue Ridge RFP again reveal the difficulties facing renewables in peaking power solicitations. 


\section{Washington}

\section{Regulatory Actions}

In 1989, the Utilities and Transportation Commission (UTC) adopted competitive bidding regulations covering regulated utilities. ${ }^{16}$ Bidding was formally established as a means to determine rates, terms, and conditions for the purchase of electricity from qualifying facilities (QFs), independent power producers (IPPs), and other utility-related entities, as well as from eligible conservation measures. Establishment of these rules does not preclude any utility from building its own capacity or purchasing power through negotiated purchase contracts in order to meet its obligation to serve.

Utilities are required to submit bidding RFPs to the UTC for approval. The UTC has given utilities the flexibility to devise their own bidding structures subject to general guidelines. The criteria used to rank project proposals must be explained in the RFP and must at a minimum address price, dispatchability, risks imposed on ratepayers, and environmental effects, including those associated with resources that emit carbon dioxide. The ranking procedures must also recognize relative amounts of risk inherent among different technologies, fuel sources, financing arrangements, and contract provisions. However, no explicit weighting scheme was proposed by the UTC.

The utility's long-run avoided costs are used as the benchmark for bid prices. QFs of $1 \mathrm{MW}$ or less in size are eligible for long-run avoided cost purchase contracts outside of the bidding process. Also, any QF can obtain a short-run purchase contract at $100 \%$ of the utility's avoided energy-only production costs outside of the bidding process. Front-loaded payments, with proper security, are permitted under the UTC rules.

\section{Bidding Status}

Two investor-owned utilities have solicited bids.

\begin{tabular}{||l|c|c|c|c||}
\hline Utility & Year & $\begin{array}{c}\text { Requested } \\
(\mathbf{a M W})\end{array}$ & $\begin{array}{c}\text { Total Selected } \\
(\mathbf{a M W})\end{array}$ & $\begin{array}{c}\text { RE Selected } \\
(\mathbf{a M W})\end{array}$ \\
\hline \hline Puget Sound P\&L \#1 & 1989 & 100 & 136.6 & $27(20 \%)$ \\
\hline Puget Sound P\&L \#2 & 1991 & $100-200$ & 121.2 & $58(48 \%)$ \\
\hline WWP & 1991 & 30 & 2.4 & 0 \\
\hline \hline
\end{tabular}

\footnotetext{
${ }^{16}$ Washington Utilities and Transportation Commission, Electric Companies-Purchases of Electricity from Qualifying Facilities and Independent Power Producers and Purchases of Electrical Savings from Conservation Suppliers, Chapter 480-107 WAC.
} 


\section{Impact on Renewables}

Puget Sound Power and Light has held two solicitations. With its first RFP (1989), Puget requested 100 average megawatts (aMW) of long-term resources (up to 20 years) from both supply and demand sources for the 1993 time frame. IPPs were allowed to bid along with QFs. A price ceiling was set by the utility's published schedule and was included in the RFP.

Following the UTC guidelines, the evaluation and ranking criteria used by Puget were based on the following: deliverability, i.e., the construction/installation schedule; price, measured as the extent to which the net present value of the bid price is less than the applicable avoided cost ceiling; financial risk, including fuel cost escalation and front-loaded payments; and non-price factors, which included consideration of environmental effects, dispatchability, system compatibility, and load shape compatibility among other factors. The scoring system for weighting these criteria was not revealed in the RFP. Avoided costs were based on available purchases through 1995 and a generic coal plant post-1995. Thus, avoided costs were low through 1995 but much higher afterward. And as stipulated in the UTC rules, front-loaded rates were acceptable to Puget given adequate risk mitigation provisions.

Forty-one project proposals, representing more than $1200 \mathrm{aMW}$ of capacity were received in response to the Puget RFP. More than one-half of the capacity offered was for natural-gas-fired projects and 23\% was renewables based, including projects utilizing wood waste, municipal solid waste (MSW), geothermal, and hydro resources. Puget selected 127 aMW of supply and 10 aMW of conservation for contract negotiation. The supply sources were a 100-MW gas-fired cogeneration facility, a 17-MW waste-to-energy project, and a 10-MW geothermal project.

Puget stated that the key selection criteria related to the following: (1) the sponsor's ability to bring the proposed project to commercial operation; (2) the ability of the proposed project to operate throughout the proposed term at the bid price, which included consideration of long-term fuel supply arrangements and environmental compliance; (3) the bid price relative to the avoided cost ceiling and other proposals; and (4) the level of economic risk placed upon Puget, including unsecured front loading of payments.

The gas-fired facility will receive front-loaded rates secured by company-owned gas reserves and a subordinate lien on the project. The waste project will receive payments containing both fixed and variable components; the latter to match Puget's avoided cost stream. And the geothermal project will receive levelized, but not front-loaded, power payments. All three projects were described by Puget as having bid prices "materially below the avoided cost ceiling."

Puget's second RFP (1991) was for 100-200 aMW of long-term resources to come on-line in the 1995-1998 period and also was open to QFs, IPPs, and conservation proposals. Puget identified six general evaluation factors: bidder ability; price; risk to Puget; environmental effects; reliability; and delivery schedule and term. The price ceiling was set by the costs of resources most recently acquired by the utility. (The payment rates for generation acquired with the first RFP ranged from 85\%-92.5\% of Puget's 1989 avoided cost.) Although the avoided cost ceiling

$$
\text { A }-47
$$




\title{
WA - Bidding Winners by Fuel Type
}

\author{
(260 aMW)
}

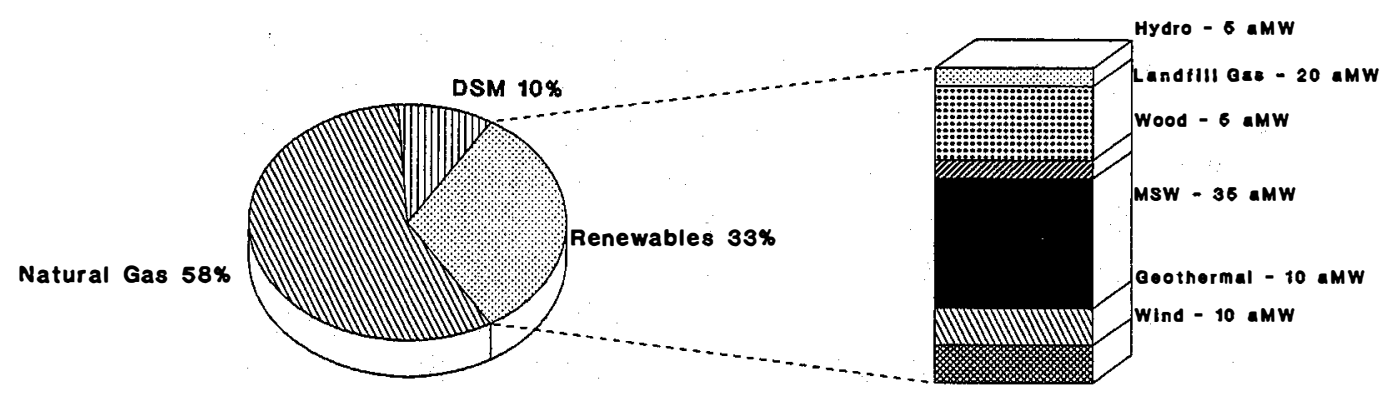

was lower, both renewable energy and conservation proposals were eligible for a $10 \%$ credit against this ceiling. Puget rationalized this credit based on the $10 \%$ credit for conservation resources contained in the Pacific Northwest Electric Power Planning and Conservation Act of 1980. (The act also required that in resource acquisition preference be given first to conservation, second to renewable resources, and third to generating sources utilizing waste heat or high fuelefficiency conversion processes before all other resources.) Contracts for 20 years or longer were preferred along, with project sizes of $70 \mathrm{MW}$ or less.

Puget selected 121.2 aMW of capacity from this second solicitation, consisting of 58 aMW of renewables (including projects utilizing wood liquor, landfill gas, MSW, hydro, and wind resources), a 50-aMW high-efficiency gas cogeneration project, and $13.2 \mathrm{aMW}$ of conservation. It was reported that all of the projects chosen offered bids at $70 \%-85 \%$ of Puget's avoided cost.

In 1991, the Washington Water Power Company (WWP) released an all-source RFP requesting $30 \mathrm{aMW}$ of long-term, firm supply beginning in 1995. Proposals were accepted from QFs, IPPs, and utilities, as well as for demand-side management (DSM) resources. WWP noted in the RFP that proposals with short lead times and flexibility in timing and size were desirable because of their attractiveness in mitigating risk associated with load growth uncertainty.

Projects were ranked based on price (50\%), viability factors (30\%), and nonprice factors (20\%). Viability factors included construction schedule, development experience, financial ability, and technological feasibility. Nonprice factors included environmental impacts, including consideration of future environmental liabilities; system compatibility; dispatchability; reliability; contract term; and the degree of preparation and progress in licensing and permitting and the 
licensing experience of the developer. WWP also included a $10 \%$ cost credit for conservation resources similar to Puget. Finally, for determining the preliminary short list of projects, WWP applied cost adders to particular resources based on environmental rankings identified in the company's 1991 least-cost planning report. The adders applied to the "preferred stack of resources" were (in levelized terms):

$\begin{array}{llll}\text { - } & \text { Renewables/system sales } & - & 2 \mathrm{mills} / \mathrm{kWh} \\ \text { - } & \text { Gas-fired cogeneration } & - & 4 \mathrm{mills} / \mathrm{kWh} \\ \text { - } & \text { Gas-fired stand-alone } & - & 6 \mathrm{mills} / \mathrm{kWh} \\ \text { Coal-fired } & - & 8 \mathrm{mills} / \mathrm{kWh}\end{array}$

WWP received 15 proposals totaling 295 MW: 200 MW of gas-fired projects; 15 MW of conservation; and $80 \mathrm{MW}$ of renewables, consisting of a hydro project and a geothermal project based in Nevada. WWP initially short-listed four projects: a 30-MW purchase from a 240-MW natural gas combined cycle plant (IPP); a 24.9-MW gas-fired cogeneration plant; a 30-MW purchase from a $210-\mathrm{MW}$ gas-fired cogeneration plant; and a 5-MW energy conservation project. No renewables projects made the short list; the cost of the hydro project was above the WWP price cap and wheeling costs worked against the geothermal project. Eventually, all the supplyside proposals were rejected because of a reduction in projected load growth. Only one DSM project (2.4 MW) was selected from all of the proposals submitted.

Renewables-based projects represent one-third of the combined capacity chosen in the two Puget solicitations, including nearly half from the second RFP. The Puget selection criteria provided a level playing field for renewables by emphasizing size, fuel diversity, and environmental considerations in addition to price. Also, the willingness to accept front-loaded payment structures and the inclusion of a $10 \%$ price adder (in the second RFP) were beneficial. To be noted, however, is that all the renewables projects selected offered prices below the utility's avoided cost. All winners consist of QFs and conservation projects, even though IPP projects were allowed to bid. The preference for small projects may have worked against IPPs (the average size of the IPP projects bid from RFP \#2 was $180 \mathrm{MW}$ ).

On the other hand, the WWP solicitation resulted in no renewables being short-listed, even though smaller sized projects were preferred and renewables received a cost comparison advantage. Furthermore, only two renewables projects were bid. 


\section{Bonneville Power Administration}

The Bonneville Power Administration (BPA) is a power marketing agency of the U.S. Department of Energy. Its primary responsibility is the marketing and transmission of power produced at federal hydropower projects and other facilities in the Pacific Northwest. BPA sells most of this power to public and private utilities located in Oregon, Washington, Idaho, and western Montana.

BPA is also authorized, under the Pacific Northwest Electric Power and Conservation Act of 1980, to acquire new resources to meet the needs of its utility customers. To this end, BPA has undertaken a competitive acquisition program for new capacity.

\section{Bidding Status}

BPA has conducted several different types of bidding solicitations.

\begin{tabular}{||l|c|c|c|c||}
\hline & Year & $\begin{array}{c}\text { Requested } \\
(\mathbf{a M W})\end{array}$ & $\begin{array}{c}\text { Total Selected } \\
(\mathbf{a M W})\end{array}$ & $\begin{array}{c}\text { RE Selected } \\
(\mathbf{a M W})\end{array}$ \\
\hline \hline Billings Credit & 1990 & 50 & 28.5 & $24.5(86 \%)$ \\
\hline Competitive Acquisition & 1991 & 300 & Pending & Pending \\
\hline Resource Contingency & 1992 & 800 & Pending & Pending \\
\hline
\end{tabular}

\section{Impact on Renewables}

In its first solicitation (1990), BPA requested proposals from its customers for supply or conservation of up to $50 \mathrm{aMW}$. Under this "billing credits" program, BPA would offer a credit on the customer's power bill equal to the difference between BPA's alternative power costs $(\sim 3 \notin / \mathrm{kWh}$ [real] or $\sim 5-6 \notin / \mathrm{kWh}$ [nominal]) and the wholesale rate paid by the utility to BPA. BPA customers responded with 85 proposals totaling 129 average megawatts (aMW) of resources. The makeup of the proposals included three gas-fired cogeneration projects totaling $49.3 \mathrm{aMW}$; nine small hydro projects (36.4 aMW); three biomass projects $(6.5 \mathrm{aMW})$; and 69 conservation projects (36.7 aMW). After a preliminary viability screening, BPA selected 28.5 aMW for negotiation; six small hydro projects $(21.5 \mathrm{aMW})$, two biomass-fired cogeneration projects ( $3 \mathrm{aMW})$, and 13 conservation projects ( $4 \mathrm{aMW})$.

In 1991, BPA expanded its bidding efforts significantly by soliciting for 100 aMW of firm resources from all sources, later increasing the request to $300 \mathrm{aMW}$ because of the large size of some of the preliminary proposals it had received. 


\title{
BPA - Bidding Winners by Fuel Type
}

\author{
(28.5 aMW)
}

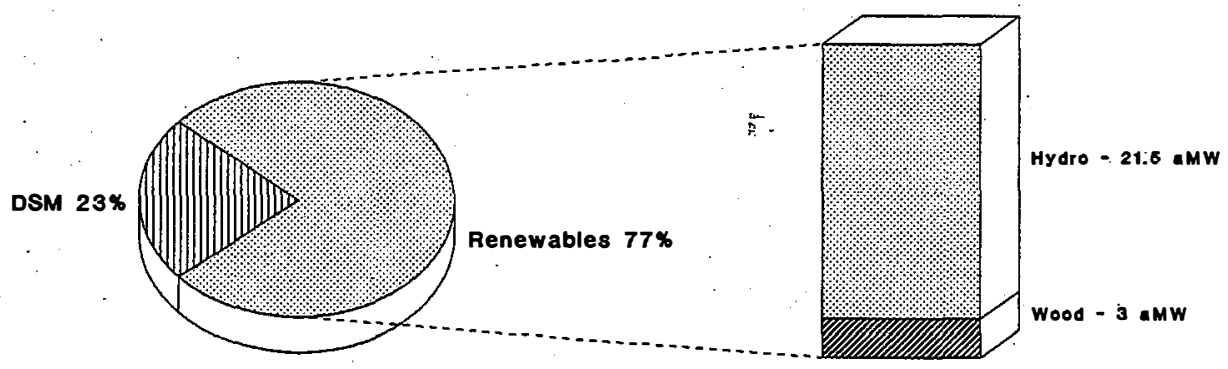

The RFP provided for a five-stage evaluation process as follows:

Stage One: Review Resource Proposal Responsiveness to Threshold Requirements

Stage Two: Determine Resource Proposal System Cost

Stage Three: Combine Conservation and Generating Proposals/Determining a Short-

List

Stage Four: $\quad$ Refine System Cost Estimates and Perform Non-Price Evaluation

Stage Five: Designate Resource Proposals for the Negotiation Group

The primary nonprice criteria considered are: (1) resource viability; (2) system operations; (3) risk; and (4) nonprice environmental impacts. The RFP notes that an otherwise cost-effective proposal may be rejected in this stage "if it presents (a) significant environmental impacts that can not be mitigated; (b) significant likelihood of not meeting the Commercial Operation Date deadline of December 31, 1997; (c) significant likelihood of inability to operate the Resource as proposed over the Contract Term; (d) unacceptable negative system operations impacts; or (e) unacceptable risk to Bonneville."

In response to this RFP, BPA received 103 proposals for a total of 5325 aMW. Natural-gas-fired projects represented $87 \%$ of the capacity proposed, followed by renewables (8\%), coal and conservation $(2 \%$ each), and system sales $(<1 \%)$. From these proposals, BPA developed a Negotiation Group consisting of 10 generation projects (1081 aMW) and 17 conservation projects (58 aMW). Of this group, renewables are represented by three projects, two wood-fired cogeneration plants ( $39 \mathrm{aMW})$ and one geothermal plant (25 aMW), for a total of $64 \mathrm{aMW}$, or $6 \%$ of the total capacity selected for negotiation. A final selection group has not yet been 
announced.

In 1992, BPA released a solicitation for $800 \mathrm{aMW}$ of resource contingency "options" for possible future development. The intent of the solicitation is to secure potentially desirable projects that can be held in a "stand-by mode" for a period of time. BPA would fund preparation work, such as permitting and design, that would allow a project to be quickly constructed when and if a resource need is later identified. In response to this solicitation, BPA received 64 proposals, totaling $7842 \mathrm{aMW}$. Only $1 \%$ of the capacity offered was renewables based. BPA later reduced this group of proposals to a short list of 10 projects totaling $2264 \mathrm{MW}$. All 10 projects are gas fired except for a 26-MW utility system sale proposal. BPA noted that it hopes to negotiate a price of about $3 \notin / \mathrm{kWh}$ (real) for generation from the final projects selected.

In parallel with these all-source bidding solicitations, BPA has developed a program of renewable resource confirmation to help advance the development of promising renewable energy technologies as well as expand knowledge of the resource base. To this end, BPA has already held resource-specific solicitations for geothermal (30 MW) and wind (50 MW) demonstrations.

It is clear that renewable energy developers are finding it difficult to compete against natural gas in the BPA solicitations at today's low natural gas fuel prices. Although the generation market in the BPA territory appears to be difficult for commercial renewable energy development at present, BPA's resource confirmation program should spur some localized renewable energy development. 


\section{New England Power}

The New England Power Company (NEP) is the wholesale generation and transmission subsidiary of the New England Electric System (NEES), a public utility holding company headquartered in Massachusetts. NEES has three retail utility subsidiaries, Massachusetts Electric Company, Narragansett Electric Company, and Granite State Electric Company, that operate in Massachusetts, Rhode Island, and New Hampshire.

\section{Bidding Status}

NEP has conducted two bidding solicitations, only one of which was all-source.

\begin{tabular}{|l|c|c|c|c|}
\hline & Year & $\begin{array}{c}\text { Requested } \\
(\mathbf{M W})\end{array}$ & $\begin{array}{c}\text { Total Selected } \\
(\mathbf{M W})\end{array}$ & $\begin{array}{c}\text { RE Selected } \\
(\mathbf{M W})\end{array}$ \\
\hline \hline RFP \#1 & 1988 & 200 & 205 & $11(5 \%)$ \\
\hline
\end{tabular}

\section{Impact on Renewables}

The first NEP solicitation was an all-source procurement for $200 \mathrm{MW}$ of capacity to be available between 1992 and 1995. The RFP did not include a ceiling price. And although nonprice factors to be considered (fuel supply, site control, anticipated environmental licensing issues, local acceptance, and integration into NEP's supply mix) were listed and discussed, the weighting procedure was not revealed. NEP received 73 project bids totaling $4728 \mathrm{MW}$. An initial screening was performed, which focused primarily on price and success factors. This screening reduced the response group to 22 projects totaling $1105 \mathrm{MW}$. Subsequently, meetings were held with the project developers focusing on "site control, local hurdles to development, fuel supply and other factors that influenced project viability." Four projects were ultimately selected, totaling $205 \mathrm{MW}$. The winners included: two independent power projects (IPPs), an 85-MW oil and an 81-MW natural gas project; and two qualifying facilities (QFs), an 11-MW waste wood and a $28-\mathrm{MW}$ coal project.

In December 1991, NEP released a first-of-a-kind RFP limited to renewable energy sources, defined to include wind, solar, biomass, waste, geothermal and hydro. The intent of this "green RFP" was to "place a limited number of renewable and waste electric power production facilities into commercial operation to assess the current-day feasibility, value, resource potential, and environmental attributes of renewable resource technologies."

NEP noted that it would purchase up to 200 million $\mathrm{kWh}$ of annual energy from such projects based on "the economics, environmental benefits and experimental value of the proposals received." Preference was to be given to projects that have minimal environmental impacts and 


\section{NEP - Bidding Winners by Fuel Type}

\section{(205 MW)}

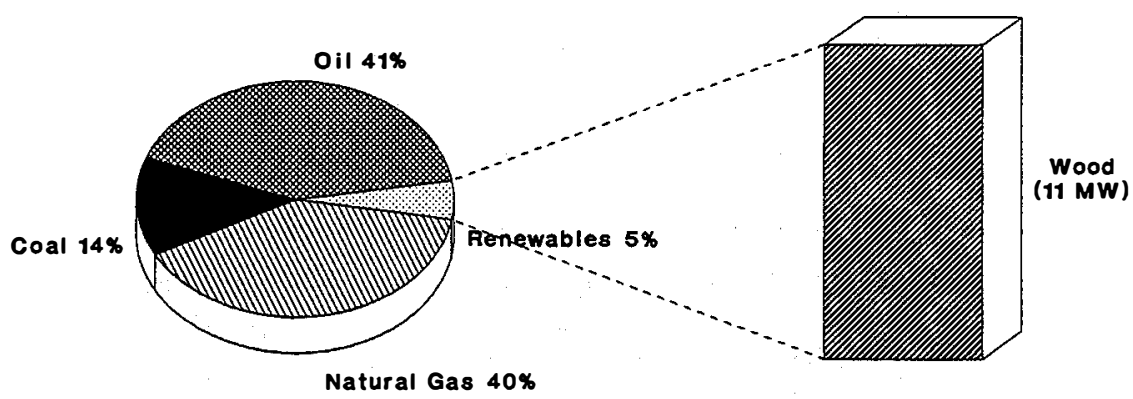

that utilize "fuels and technologies not fully explored in New England," such as advanced wind energy technology and biomass projects using fast growing wood species. In response, NEP received 41 proposals totaling 1.4 billion $\mathrm{kWh}$ of annual generation (256 MW of capacity), from projects using solar, small hydro, advanced wind, landfill gas, biomass, and municipal solid waste (MSW). NEP has yet to make a final determination on the RFP winners. However, based on this response, the utility noted that it

... found that creative ideas and solutions are available in the New England renewables market. Moreover, the price for many of the projects received are at or are approaching levels realistic for commercial operation. Although all the projects exceed NEP's currently forecasted avoided costs (energy-only), the incremental value they bring in terms of learning and potential environmental benefits makes some level of commitment worthwhile at this time. 


\section{PacifiCorp}

PacifiCorp is a utility holding company that operates in seven western states (Washington, Oregon, Califormia, Idaho, Utah, Montana, and Wyoming) through its retail subsidiaries, Pacific Power and Utah Power.

\section{Bidding Status}

PacifiCorp has held one bidding solicitation.

\begin{tabular}{|l|c|c|c|c||}
\hline & Year & $\begin{array}{c}\text { Requested } \\
(\mathbf{a M W})\end{array}$ & $\begin{array}{c}\text { Total Selected } \\
(\mathbf{a M W})\end{array}$ & $\begin{array}{c}\text { RE Selected } \\
(\mathbf{a M W})\end{array}$ \\
\hline \hline RFP \#1 & 1991 & 50 & 21.5 & $5.9(27 \%)$ \\
\hline
\end{tabular}

\section{Impact on Renewables}

PacifiCorp issued a bidding RFP in 1991 for 50 average megawatts (aMW) of long-term, firm resources. Both supply-side and demand-side resources were requested, with supply-side participation limited to non-utility generators, i.e., qualifying facilities (QFs) and independent power producers (IPPs). The bid prices were to be compared to the utility's avoided cost on a net present value basis; security was to be required if payments to the developer would exceed the utility's price stream, i.e., for front-loading of payments. These price factors account for at least $50 \%$ of the evaluation weighting. Other evaluation criteria noted (but not quantified) included commercial availability and maturity of the technology; site control; development experience; development plan; financing; system compatibility; fuel supply; and environmental factors. The environmental factors, including consideration of residual environmental costs and general environmental externalities, were to account for at least $10 \%$ of the evaluation weighting. In addition, the developer is responsible for arranging and paying for transmission and interconnection, including operation and maintenance costs.

Forty-seven proposals were received in response to the PacifiCorp RFP, totaling more than 1100 MW of capacity. Renewable-energy-based projects represented $17 \%$ of the projects and $12 \%$ of the capacity offered. PacifiCorp ultimately selected three demand-side management (DSM) projects totaling $15.6 \mathrm{MW}$, and two small hydro projects totaling $5.85 \mathrm{MW}$. It was reported that environmental concerns, as well as project location and the financial condition of bidders, limited the selection to less than half of the capacity originally sought. 


\section{PCorp - Bidding Winners by Fuel Type}

\section{(21.5 MW)}

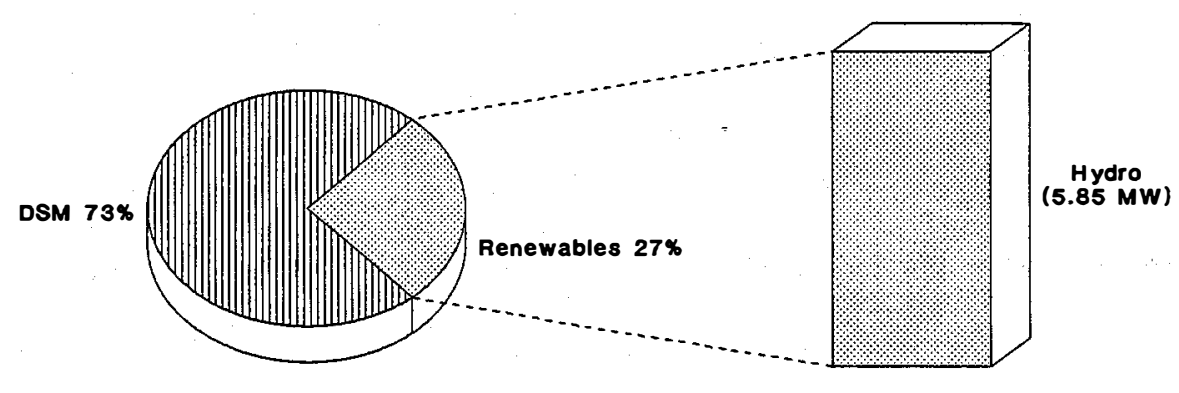

A - 56 


\begin{tabular}{|c|c|c|c|}
\hline $\begin{array}{c}\text { Document Control } \\
\text { Page }\end{array}$ & $\begin{array}{l}\text { 1. NREL Report No. } \\
\text { NREL-TP-462-5479 }\end{array}$ & $\begin{array}{l}\text { 2. NTIS Accession No. } \\
\text { DE93010030 }\end{array}$ & 3. Recipient's Accession No. \\
\hline \multirow{2}{*}{\multicolumn{3}{|c|}{$\begin{array}{l}\text { 4. Title and Subtitle } \\
\text { The Impact of Competitive Bidding on the Market Prospects for } \\
\text { Renewable Electric Technologies }\end{array}$}} & $\begin{array}{l}\text { 5. Publication Date } \\
\text { September } 1993\end{array}$ \\
\hline & & & 6. \\
\hline \multicolumn{3}{|l|}{$\begin{array}{l}\text { 7. Author(s) } \\
\text { B. Swezey }\end{array}$} & 8. Performing Organization Rept. No. \\
\hline \multirow{2}{*}{\multicolumn{3}{|c|}{$\begin{array}{l}\text { 9. Performing Organization Name and Address } \\
\text { National Renewable Energy Laboratory } \\
1617 \text { Cole Boulevard } \\
\text { Golden, Colorado } 80401-3393\end{array}$}} & $\begin{array}{l}\text { 10. Project/Task/Work Unit No. } \\
\text { AS } 815440\end{array}$ \\
\hline & & & $\begin{array}{l}\text { 11. Contract (C) or Grant (G) No. } \\
\text { (C) } \\
\text { (G) }\end{array}$ \\
\hline \multirow{2}{*}{\multicolumn{3}{|c|}{ 12. Sponsoring Organization Name and Address }} & $\begin{array}{l}\text { 13. Type of Report \& Period Covered } \\
\text { Technical Report }\end{array}$ \\
\hline & & & 14. \\
\hline \multicolumn{4}{|c|}{ 15. Supplementary Notes } \\
\hline \multicolumn{4}{|c|}{$\begin{array}{l}\text { 16. Abstract (Limit: } 200 \text { words) } \\
\text { This report examines issues regarding the ability of renewable-energy-based generation projects to compete with } \\
\text { fossil-fuel-based projects in competitive bidding solicitations. State and utility bidding results revealed that, on a } \\
\text { relative basis, utilities contract for less renewable-energy-based capacity under competitive bidding than under past } \\
\text { methods of qualifying facility contracting. It was concluded that renewables are not being chosen more often } \\
\text { under competitive bidding because it emphasizes price and operating considerations over other attributes of } \\
\text { renewables, such as environmental considerations, fuel diversity, and fuel price stability. Examples are given of } \\
\text { bidding approaches used by some states and utilities that have resulted in renewables-based projocts winning } \\
\text { generation bids. In addition, the appendix summarizes, by state, competitive bidding activities and results for } \\
\text { supply-side solicitations that were open to all fuels and technologies. }\end{array}$} \\
\hline \multicolumn{4}{|c|}{$\begin{array}{l}\text { 17. Document Analysis } \\
\text { a. Descriptors } \\
\text { competitive bidding; market prospects; renewable electric technologies } \\
\text { b. Identifiers/Open-Ended Terms }\end{array}$} \\
\hline \multicolumn{4}{|l|}{$\begin{array}{l}\text { c. UC Categories } \\
233\end{array}$} \\
\hline \multirow{2}{*}{\multicolumn{3}{|c|}{$\begin{array}{l}\text { 18. Availability Siotement } \\
\text { National Technical Information Service } \\
\text { U.S. Department of Commerce } \\
\text { 5285 Port Royal Road } \\
\text { Springfield, VA } 22161\end{array}$}} & $\begin{array}{l}\text { 19. No. of Pages } \\
86 \\
\end{array}$ \\
\hline & & & $\begin{array}{l}\text { 20. Price } \\
\text { A05 }\end{array}$ \\
\hline
\end{tabular}

Form No. 0069E (6-30-87) 